\title{
Crime e castigo: as técnicas do narrador onisciente (excertos)
}

\section{Gary Rosenshield}

Nota da tradutora: Gary Rosenshield é PhD pela Universidade de Wisconsin-Madison e foi professor emérito do departamento de Língua e Literatura Eslavas na mesma universidade. Autor de Western Law, Russian Justice: Dostoesvky, the Jury Trial, and the Law e Pushkin and the Genres of Madness: The Masterpieces of 1833. Publicou também o estudo Crime and Punishment: The Techniques of the Omniscient Author (Lisse: The Peter de Ridder Press, 1978), do qual foram traduzidos a introdução e dois capítulos: "O narrador, Raskólnikov e o epílogo" e "O ponto de vista elevado". Joseph Frank, no capítulo em que aborda o processo de criação de Crime e castigo, cita, em nota, esse estudo, recomendando-o como uma "análise cuidadosa e perspicaz" e "um dos melhores estudos dedicados ao romance" (FRANK, Joseph. Dostoiévski: Os anos milagrosos, 1865-1871. São Paulo: Edusp, 2003, p. 125). Victor Terras engrossa o coro elogioso ao afirmar tratar-se de uma "excelente análise" (TERRAS, Reading Dostoevsky. Wisconsin: The University of Wisconsin Press, 1998, p. 63).

Translator's note: Gary Rosenshield is a PhD at the University of Wisconsin-Madison and was a professor at the Department of Slavic Languages and Literature at the same university. He is the author of Western Law, Russian Justice: Dostoevsky, the Jury Trial, and the Law and Pushkin and the Genres of Madness: The Masterpieces of 1833. He has also published Crime and Punishment: The Techniques of the Omniscient Author (Lisse: The Peter Ridder Press, 1978) from which we present the translation of the introduction and two chapters ("The Narrator, Raskolnikov, and the Epilogue" and "The Higher Point of View"). Joseph Frank, while discussing the creation process of Crime and Punishment, mentions Rosenshield's study and recommend it as a "careful and perceptive analysis" and "one of the best studies devoted to the novel" (Dostoevsky: The Miraculous Years - 1865-1871, Princeton University Press, 1995). Victor Terras adds to the complimentary tone by saying that it is an excellent analysis (Reading Dostoevsky, The University of Wisconsin Press, 1998). 


\section{Capítulo 1 - INTRODUÇÃO}

Não é surpreendente que o papel do narrador em Crime e castigo tenha recebido pouca atenção dos estudiosos ${ }^{1}$. Enquanto outros grandes romances de Dostoiévski têm narradores pessoais e dramatizados, o narrador de Crime e castigo é comparativamente inconspícuo. Ele não é nem o herói, como em $O$ adolescente, nem mesmo um personagem da história, como em Os demônios e Os irmãos Karamázov, e está longe do tagarela narrador intruso de $O$ idiota. Seu sucesso relativo em escapar à detecção, entretanto, levou a uma injustificável negligencia crítica; pois, entre todos os narradores de Dostoiévski, ele é, talvez, o mais crucial para nossa percepção dos personagens e eventos. De fato, pode se argumentado que o mundo de Crime e castigo é o mundo do narrador. Compreender seu papel não só possibilita uma apreciação mais profunda do texto, mas uma investigação do romance como gênero literário. Como afirma Wolfgang Kayser, a força vital do romance é o narrador, sem o qual ele não passa de uma concha vazia $^{2}$.

Infelizmente, o pouco que tem sido feito sobre os narradores dos outros grandes romances de Dostoiévski tem aplicação bastante limitada a Crime e castigo por dois motivos. Primeiro, o narrador neste romance difere muito dos narradores de outras obras de Dostoiévski. Ele raramente usou narradores objetivos de terceira pessoa, tendo preferido o narrador em primeira ou terceira pessoa altamente dramatizado. Por isso,

\footnotetext{
${ }^{1} \mathrm{O}$ artigo de Pierre R. Hart, "Looking over Raskol'nikov's Shoulder: The narrator in 'Crime and Punishment"”, Criticism, 13 (1971), 166-79, é, até o momento, o trabalho mais informativo sobre o assunto. A maioria dos outros trabalhos sobre a narração em Crime e castigo pode ser encontrada em comentários esparsos em muitos livros e artigos. Ver, por exemplo, Julius Méier-Graefe, Dostoevsky: The Man and His Work, traduzido por Herbert H. Marks (New York: Harcourt: 1928, p. 112; Joseph Warren Beach, The Twentieth Century Novel: Studies in Technique (New York: Appleton, 1932), pp. 155-7, 1946; F. I. Evnin, "Roman 'Prestuplenie i nakazanie"” em Tvortchestvo Dostoievskogo, editado por N. L. Stepanov. (M.: AN SSSR, 1959), p. 169; Lászlo Karantchi, "K problematike pisatelnoi manery Dostoiévskogo", Slavica, 1 (1961), 135-55; Ia. O. Zundelovitch, Romany Dosotoiévskogo: Stat'i (Tachent: Sredniaia i vischaia chkola, 1963), pp. 10-61; G. M. Fridlender, Realizm Dostoiévskogo (M. L.: AN SSSR, 1964), pp. 170-4, 190-1; F. I. Evnin, "O nekotorizh voprossakh stilia i poetiki Dostoievskogo". Isvestia Akademii nauk, 24, no 1 (1965), 68-80; Edward Wasiolek, F. M. Dostoevsky, The Notebooks for "Crime and Punishment" (Chicago: University of Chicago Press, 1967), pp. 9-10, 100-2; V. I. Etov, Dostoievski, Otcherk tvortchestva (M.: Prosveschnie, 1968), p. 195; L. D. Opulskaia, "Istoria sozdania romana", em F. M. Dostoiévski, "Prestuplenie i Nakazanie", editado por L. D. Opulskaia e F. G. Kogan (M.: Naúka, 1970), p. 688; A. A. Belkin, Tchitaia Dostoievskogo i Tchekhov (M. Khudojestvennaia lit., 1973), p. 73-4; V. N. Toporov, "O strukture romana Dostoievskogo 'Prestuplenie i nakazanie"' em Structure of Texts and Semiotics of Culture, Ed. Jan van der Eng e Mojmir Grygar (The Hague: Mouton, 1973), pp. 225-302; V. A. Misliakov, 'Kak rasskazana 'istoria' Rodiona Raskol'nikova”, em Dostoiévski: Materiali i issledovania, Ed. G. M. Fridlender (L.: Nauka, 1974), PP. 147-63.

${ }^{2}$ Ver Wolfgang Kayser, Entstehung und Krise des modernen Romans [Formação e crise do romance moderno], $2^{\circ}$ edição (Stuttgart: J. B. Metzlersche Verlagsbuchhandlung, 1955).
} 
observações, por exemplo, acerca do narrador em primeira pessoa de $O$ Adolescente dificilmente podem esclarecer o uso do narrador em terceira pessoa de Crime e castigo. Segundo, a maior parte das análises do ponto de vista nos romances de Dostoiévski falhou na apreciação da sofisticação de suas técnicas. Elas raramente, se é que alguma vez o fizeram, distinguem autor implícito, narrador e o Dostoiévski histórico, descuido crítico este que levou a graves interpretações errôneas. Poucos identificariam o narrador de $O$ adolescente, Arkadi Dolgoruki, com o autor implícito ou o Dostoiévski histórico; mas críticos têm visto Dostoiévski não somente no narrador de Os demônios, como também em Makar Diévuchkin, o herói de Gente pobre ${ }^{3}$. Tampouco o autor implícito dos romances de Dostoiévski é sempre idêntico ao autor histórico. Quando artisticamente necessário, Dostoiévski apresenta suas ideias mais estimadas numa chave ambígua. As ideias de Chatov sobre a Ortodoxia Russa - virtualmente idênticas às de Dostoiévski - são apresentadas com tanto ceticismo quanto o delírio suicida de Kirilov.

A visão mais difundida sobre os narradores de Dostoiévski consiste em que eles são essencialmente objetivos, servindo a assim chamada "função informativa". De acordo com essa opinião, Dostoiévski é um romancista dramático, que prefere mostrar a contar, e quando, ocasionalmente, narra, seus relatos são meramente resumos sóbrios e concisos das informações necessárias. Em outras palavras, diferente de escritores como George Eliot, Dickens ou Gógol, Dostoiévski raramente assume o papel de um autor onisciente intruso. Contudo, a afirmação de que os narradores de Dostoiévski são objetivos é uma posição que não resiste à análise crítica. Se por objetividade compreendemos pouca intrusão autoral, então é verdade que Crime e castigo é mais objetivo de que a maioria dos romances russos e europeus contemporâneos à Dostoiévski. Mas não é tão objetivo quanto muitos romances em terceira pessoa escritos durante o século XX, ou mesmo tão objetivo quanto frequentemente se defende. De fato, eu pretendo demonstrar que o narrador em Crime e castigo, por uma variedade de

\footnotetext{
${ }^{3}$ Para uma identificação explícita entre Dostoiévski e Diévuchkin ver Likhatchóv, "Letopisnoe vremia u Dostoiévskogo", em Poética drevnerusskoi literatury (L.: Nauka, 1967), pp. 321-2.

${ }^{4}$ Ver, por exemplo, Lunatchárski, “O ‘mnogogolosnosti’ Dostoiévskogo”, em F. M. Dostoiévski v russkoi kritike: Sbornik statei, Ed. A. A. Belkin (M.: GIXL, 19560), p. 413; G. I. Tchulkov, Kak rabotal Dostoiévski (M.: Sov. Pisatiel', 1939), pp. 81, 146; Evnin, "Prestuplenie i nakazanie”, p. 109; L. P. Grossman, "Dostoiévski - khudojnik", em Tvortchestvo Dostoievskogo, pp. 353-4 [Dostoiévski artista. Trad. Boris Schnaiderman. Rio de Janeiro: Civilização Brasileira, 1967]; Karantchi, p. 142; M. M. Bakhtin. Problemi poetiko Dostoievskogo, $2^{\circ}$ edição (M. Sov. Pisatiel', 1963) p. 336 [Problemas da poética de Dostoiévski. Trad. Paulo Bezerra. Rio de Janiero: Forense Universitária, 2008]; Fridlender, p. 190; V. I. Etov, "Manera povestvovania v romane Dostoiévskogo Idiot", Vestnik Moskovskogo universiteta, 21, no 1 (1966), 74.
} 
meios, sendo alguns sutis e outros óbvios, desempenha um papel essencial na estrutura retórica do romance.

Mesmo as melhores análises dos narradores dostoievskianos são arruinadas por sérias falhas analíticas. Van der Eng, por exemplo, argumenta que Dostoiévski usa técnicas diferentes para protagonistas e personagens secundários ${ }^{5}$. Ele sustenta que o autor emprega onisciência tradicional ao lidar com personagens menores e que protagonistas são apresentados por meio do discurso, ação e transcrição da consciência, ou seja, objetiva e dramaticamente. Muito embora a confusão que van der Eng faz entre narrador e autor implícito torne seu argumento inaplicável para o todo da obra de Dostoiévski, sua descrição parece, à primeira vista, um tanto adequada para o narrador de Crime e castigo. Entretanto, a divisão dos personagens em dois grupos é altamente discutível. São Marmieládov, Svidrigáilov e Porfíri Pietróvitch realmente mais importantes que Katierina Ivanovna, Lújin e Razumíkhin? Além disso, van der Eng deixa de observar que Dostoiévski frequentemente utiliza técnicas tradicionais para os ditos personagens principais e técnicas dramáticas para os menores.

A abordagem mais radical dos romances de Dostoiévski foi formulada por Mikhail Bakhtin, o qual, já em 1929, defendeu que o tratamento da narração feito por Dostoiévski marcou um estágio revolucionário no desenvolvimento do romance ${ }^{6}$. Embora as generalizações de Bakhtin sejam exageradas e sua terminologia imprecisa, sua obra é, não obstante, provocativa. Bakhtin vê a diferença essencial entre o romance dostoievskiano (polifônico) e o tradicional (monofônico) na relação entre a dramatis personae e aquilo que ele denomina voz do autor. Enquanto no romance tradicional, a voz do autor é um centro dominante estrutural e avaliativo ao qual todas as outras vozes (pontos de vista) estão subordinadas; no romance polifônico, a voz do autor é igual, e não mais importante, do que as vozes dos principais personagens. Para Bakhtin, Dostoiévski criou um novo tipo de romance ao incorporar o ponto de vista do narrador monofônico à consciência de seu herói, equipando-o, assim, com a perspectiva e o conhecimento do narrador intrusivo tradicional. Uma vez que a primazia da voz do autor teve de ser eliminada para que o herói se tornasse completamente independente, Dostoiévski transformou seu narrador num narrador objetivo, um mero disseminador de informações.

\footnotetext{
${ }^{5}$ Johannes J. van der Eng, Dostoievskij romancier: Rappports entre sa vision du monde et ses procédés littéraires (The Hague: Mouton, 1957), pp. 75-91.

${ }^{6}$ A segunda edição do trabalho de Bakhtin (ver nota 4) difere pouco no argumento essencial em relação à edição de 1929.
} 
Considerando que Bakhtin raramente distingue os termos "autor", "voz do autor" e "narrador", é difícil, em muitas situações, entender seu sentido exato ${ }^{7}$. Além disso, os problemas criados por essa imprecisa terminologia são acrescidos de sua falha em aplicar essas visões sistematicamente à principal ficção de Dostoiévski. Quando usamos suas teorias para elucidar o ponto de vista nos últimos romances, chegamos a resultados decepcionantes. Pode o narrador ter um ponto de vista igual àquele dos personagens e ainda ser simplesmente um disseminador de informação? Em $O s$ demônios, qual ponto de vista do narrador é igual ao de Stavróguin? O do cronista? O autor onisciente? Embora seja possível argumentar que o ponto de vista de Stavróguin é tão importante quanto o do cronista, certamente não é tão válido quanto o do autor onisciente. É verdade que o ponto de vista do narrador-protagonista de $O$ adolescente, Arkadi Dolgoruki, possa não ser mais válido do que o de outros personagens, mas o narrador aqui é extremante subjetivo, longe de ser um mero disseminador de informações. De fato, pareceria que os narradores de Dostoiévski simplesmente reduziriam o impacto de seus pontos de vista ao tentar abertamente impô-los aos outros. É o narrador aparentemente objetivo de Crime e castigo, o narrador que menos visivelmente tenta submeter o ponto de vista dos personagens ao seu próprio, que acaba sendo o mais bem sucedido em fazê-lo. Tudo que acontece em Crime e castigo está subordinado a um ponto de vista elevado decifrável e cuidadosamente trabalhado, e, ao contrário do que Bakhtin defende, o romance não é mais polifônico do que as obras dos contemporâneos de Dostoiévski. Assim, a alegação de que Dostoiévski aumentou a objetividade de seu narrador para assegurar a mesma validade a todos os pontos de vista do romance é errônea no caso de Crime e castigo e tem pouca, senão nenhuma, aplicabilidade aos outros grandes romances de Dostoiévski.

$\mathrm{Na}$ verdade, as observações do próprio Dostoiévski na escolha do narrador para Crime e castigo são mais elucidativas de que as dos críticos. Num apontamento de seu caderno feito um mês antes da primeira parte do romance ser mandada para o editor, Dostoiévski cogitou a possibilidade de uma narração em terceira pessoa ${ }^{8}$. Até então, Crime e castigo havia sido uma confissão em primeira pessoa. Neste apontamento,

\footnotetext{
${ }^{7}$ Os termos em russo são avtor (autor), golos avtora (voz do autor), rasskaztchik ou povestvovatel' (narrador).

${ }^{8}$ Rosenshield informa que as citações do romance e do caderno de notas foram por ele traduzidas a partir da seguinte edição original: F. M. Dostoievski, Prestuplenie i nakazanie, Ed. L. D. Opulskaia e G. F. Kogan. Literaturnie pamiatniki; M.: Nauka, 1970, p. 541. Para a presente tradução, recorreremos à edição em português: Dostoiévski, F. M. Crime e castigo. Tradução Paulo Bezerra. São Paulo: Editora 34, 2001. (N. da T.)
} 
Dostoiévski propõe um narrador onisciente, infalível e invisível que não deixaria seu herói (Raskólnikov) por um momento sequer. Na versão final do romance, o narrador é, de fato, onisciente e infalível; não é um personagem na história, mas uma consciência divina superior, que, em consonância com a prática ficcional estabelecida no século XIX, sabe tudo que acontece tanto no mundo externo quanto nas mentes dos personagens. As informações e opiniões do narrador simplesmente não são passíveis de questionamento. Elas são confirmadas pelo enredo, pelo simbolismo e pela estrutura do romance. Dessa forma, o narrador é, em todo romance, um porta-voz do autor implícito.

Este narrador, contudo, não é invisível; nem fica com Raskólnikov do início ao fim. Dostoiévski deve ter mudado de ideia em relação ao plano original algum tempo antes de submeter a primeira parte ao editor, porque, na versão final do romance, o narrador é significativamente personalizado, senão dramatizado, e frequentemente deixa seu herói para fornecer material do pano de fundo e transcrever cenas em que Raskólnikov não está presente. Diferentemente do maduro James, Dostoiévski não tenta filtrar todos os eventos por meio de uma inteligência central.

\section{Capítulo 9 - O NARRADOR, RASKÓLNIKOV E O EPÍLOGO}

Muitos dos comentários mais evidentes do narrador em Crime e castigo relacionam-se a personagens como Pulkhéria Alexandrovna, Lújin e Razumíkhin. Contudo, o principal propósito destes comentários não consiste na avaliação de personagens secundários, mas do protagonista. Afirmações explícitas - frequentemente bruscas e pungentes - sobre outros personagens constituem uma das técnicas mais eficazes do narrador para revelar sua atitude em relação à Raskólnikov.

Ainda assim, há uma grande quantidade de comentários avaliativos direcionados a Raskólnikov. Estes são observados com menor frequência porque tendem a ser mais implícitos do que explícitos, mais sutis do que intrusivos, e porque geralmente são incorporados à transcrição da consciência de Raskólnikov. Eu mostrei como uma leve imitação ou um ocasional "assim lhe parecia" são suficientes para conferir aos pensamentos de Raskólnikov um aspecto irônico. De fato, virtualmente todas as passagens longas de consciência narrada e todas das análises mentais são batalhas polêmicas entre o narrador e seu protagonista. E essa batalha é claramente desigual. Não 
sendo visto por seu oponente e impérvio ao contra-ataque, o narrador marca todos os pontos. Ao final do romance, o efeito combinado destas incontáveis alfinetadas pesa contra Raskólnikov tanto quanto os comentários indiretos.

Foi mencionado que o escasso uso de comentários fortes sobre Raskólnikov torna a apresentação do protagonista mais dramática e vívida. Outra razão relaciona-se com a maneira pela qual Raskólnikov é desenvolvido ao longo da obra.

É um lugar-comum da crítica a afirmação de que o romance realista russo do século XIX enfatiza a caracterização à custa do enredo ${ }^{9}$. Tal julgamento tem obviamente menos relevância para Dostoiévski do que para escritores como Gontcharóv, Tolstói e Turguêniev, mas poucos questionariam sua aplicabilidade à Crime e castigo. Ainda assim, poderia surpreender muitos leitores anglo-americanos o fato de que o drama psicológico de Crime e castigo quase nada tem a ver com desenvolvimento de caráter - para alguns, condição sine qua non da grande ficção. Realmente, não há qualquer desenvolvimento do caráter no romance. É claro que Raskólnikov passa por uma mudança inquestionável no epílogo, no entanto, trata-se mais de uma transformação miraculosa do que um processo psicologicamente motivado e demonstrado. Raskólnikov não se emenda gradualmente, ele ressurge dos mortos, passa por uma transformação que desafia as leis do tempo e de causalidade às quais a maioria dos romances oitocentistas adere. Ele é essencialmente a mesma pessoa cativa de antes do crime. Apesar de debilitado e abatido, ele preserva seu orgulho ilimitado e sustenta suas teorias racionalistas até o último capítulo do epílogo. O drama de Crime $e$ castigo resulta não do desenvolvimento do caráter, mas de uma longa e lenta revelação da personalidade de Raskólnikov. E aí reside a explicação para Dostoiévski ter restringido o uso de comentários fortes sobre Raskólnikov. Pois fica claro que qualquer tentativa por parte do narrador em categorizar muito rigidamente ou explicar de modo muito simplório a essência de seu herói resolveria o enigma da personalidade de Raskólnikov, e, assim, removeria a pedra fundamental da estrutura dramática do romance.

Contudo, em Crime e castigo, os comentários diretos sobre Raskólnikov - as análises das motivações do herói, os apartes irônicos, os epítetos descritivos, as

\footnotetext{
${ }^{9}$ D. S. Mirsky, em History of Russian Literature from the Earliest Times to the Death of Dostoevsky (Nova Iorque: Knopf, 1927), p. 218-19, afirma que "outra característica que . . . lhes é típica [aos realistas] como escola é a relativa negligência da construção e do interesse narrativo, e a concentração nos interesses extra-narrativos, nos personagens e na introspecção. A esse respeito, o romance russo, especialmente Tolstói, estava muito longe do romance europeu da época e foi superado pelos romancistas ocidentais somente na obra final de Henry James, na obra de Proust e de James Joyce".
} 
reminiscências sugestivas e, finalmente, as famosas seções retóricas do epílogo nas quais o narrador muda subitamente e torna-se direto - todos eles desempenham um papel crucial ${ }^{10}$.

Um exemplo bastante notável de comentário direto é o relato do narrador sobre as reflexões de Raskólnikov imediatamente antes do assassinato. Esse comentário não é nem de longe tão pesado quanto àquele sobre Lebeziátnikov, nem tão aberto e franco como no epílogo. Ainda assim, embora seja menos intenso, ele é, aqui e ali, inequívoca e notavelmente eficiente em minar o herói.

Mas isso ainda eram minúcias sobre as quais ele nem tinha começado a pensar, e também não tinha tempo para isso. Pensava no principal, e adiava as minúcias até o momento em que ele mesmo estivesse convencido de tudo. Mas este último lhe parecia terminantemente inexequível. Pelo menos era o que parecia a ele mesmo. Nunca podia, por exemplo, imaginar que um dia parasse de pensar, se levantasse e simplesmente caminhasse para lá... até mesmo aquele seu ensaio recente (isto é, a visita que fizera com a intenção de estudar definitivamente o lugar) ele apenas esboçara, mas nem de longe para valer, fizera por fazer: "deixa eu ir lá, articulou ele, experimentar, por que ficar nesse devaneio!?" - e no mesmo instante não se conteve, mandou tudo às favas e saiu de supetão, furioso consigo mesmo. Enquanto isso, porém, parecia que já havia concluído toda a análise no sentido da solução moral da questão: sua casuística estava afiada como uma navalha, e em si mesmo ele já não encontrava objeções conscientes. Mas no último caso ele simplesmente não acreditava em si mesmo e procurava de modo obstinado e servil objeções por todos os lados e às apalpadelas, como se alguém o forçasse e o arrastasse para tal. O último dia, que começara tão por acaso e resolvera tudo de uma só vez, agia sobre ele de maneira quase inteiramente mecânica: como se alguém o segurasse pelo braço e o arrastasse, de forma irresistível, cega, como uma força antinatural, sem

\footnotetext{
${ }^{10}$ Para exemplos de comentários narrativos diretos sobre Raskólnikov discutidos em capítulos anteriores, ver pp. 21-2, 53-4, 57-8, 63-7, 87-8.
} 
objeções. Como se uma nesga de sua roupa tivesse caído debaixo de uma roda de máquina e esta começasse a tragá-lo. (p. 84-5) ${ }^{11}$

A essa altura Raskólnikov não havia se comprometido irrevogavelmente com o assassinato. Embora já tivesse feito muitos preparativos importantes, como arrumar um penhor falso e costurar um laço dentro do casaco para o machado, ele ainda não conseguia acreditar que superaria sua paralisia intelectual e realmente realizar a façanha. Essa passagem difere da maioria das seções em que os pensamentos de Raskólnikov são expostos, no sentido de que tudo aqui é contado do ponto de vista do narrador. De fato, é mais uma análise do narrador do que uma transcrição. Não há uma frase sequer em que ele não coloque seriamente em questão os motivos de Raskólnikov ou sua compreensão da situação.

No início do parágrafo, Raskólnikov rejeita os detalhes do plano de seu crime como minúcias que podem ser adiadas até que ele chegue a uma decisão final - matar ou não matar. Ele mal pode conceber, contudo, que o momento está chegando, que ele vai cometer o assassinato em questão de horas, e que essas minúcias, que ele sumariamente se recusa a considerar, estão destinadas a desempenhar um papel crucial na bem-sucedida perpetração do crime. O narrador, dotado de percepção tardia, sabe disso muito bem, e não podemos deixar de perceber sua ironia no tratamento dos erros de cálculo de Raskólnikov. Num certo sentido, o assassinato de Aliona Ivanovna por Raskólnikov é uma absurda comédia de erros, na qual o assassino tem êxito apesar de seu descuido. Todos os seus cálculos estão errados, desde esperar encontrar o machado na cozinha, até presumir que a irmã da usurária estaria fora durante o assassinato. Ele é salvo de seus erros de cálculo não por sua perspicácia, da qual ele tanto se orgulha, mas pela mais extraordinária concatenação de circunstâncias: ele encontra o machado por acaso no apartamento do zelador; entra no apartamento da usurária protegido por uma carruagem; não encontra ninguém no caminho; escapa escondendo-se num apartamento vazio - convenientemente esvaziado minutos antes -; vai embora sem ser percebido pelas pessoas reunidas na frente do prédio; retorna com segurança para sua casa; devolve o machado; e entra em seu quarto sem encontrar uma única alma. Ironicamente, as minúcias cuidaram de si mesmas; se ele tivesse planejado com mais cuidado, ou errado menos, dificilmente teria tido mais sucesso. Mas Raskólnikov não é grato por seu

\footnotetext{
${ }^{11}$ As citações de Crime e castigo foram retiradas da seguinte edição em português: Dostoiévski, F. M. Crime e castigo. São Paulo: Editora 34, 2001, com tradução de Paulo Bezerra (N. da T.)
} 
sucesso, uma vez que este sarcasticamente revela sua inépcia e insignificância: ele provou a si mesmo ser uma mera paródia do seu ideal napoleônico.

Entretanto, a ironia do narrador se torna evidente somente na quarta frase. Depois de afirmar que Raskólnikov não conseguia acreditar que era capaz de levar o plano a termo, o narrador comenta: "Pelo menos era o que parecia a ele mesmo". A implicação é clara: Raskólnikov está tão equivocado em relação a suas próprias capacidades quanto sobre o que vai acontecer. O comentário interpolado, chamando atenção para a patente falta de autoconhecimento de Raskólnikov, claramente revela a atitude condescendente do narrador em relação a seu herói e, ao mesmo tempo, possibilita uma introdução irônica ao comentário mais importante que se segue.

O narrador reserva sua mais forte censura para justificativa moral de Raskólnikov para seu crime. Ele parece ter dúvidas apenas sobre a execução do ato e não sobre suas implicações morais. Aqui, da mesma forma que na quarta frase, uma expressão avaliativa - "parecia" - revela a atitude irônica do narrador em relação à posição moral de Raskólnikov. Mas a expressão pode ser também uma forma de criar surpresa retórica. É como se o próprio narrador se impressionasse com o fato de que, para Raskólnikov, as questões morais são mais fáceis de resolver do que as práticas. O uso da palavra casuística tem sentido especialmente condenatório; pois o termo russo (kazuistika) tem toda a força negativa de sua contraparte em inglês: a aplicação equivocada de princípios éticos para casos individuais de conduta ou consciência. A aproximação que o narrador faz entre a casuística de Raskólnikov e uma navalha sugere seu perigo potencial e, pelo menos metaforicamente, liga o pensamento distorcido de Raskólnikov ao assassinato que ele em breve cometerá.

Tendo desafiado as racionalizações de Raskólnikov sobre o assassinato contemplado, o narrador passa a detonar as pretensões napoleônicas de seu herói. Mesmo antes de o vermos agir de modo desajeitado no crime, Raskólnikov é apresentado não como um homem que dá forma aos eventos, à exemplo das figuras da história mundial com as quais ele se compara, mas como um objeto passivo, manipulado por forças além do seu controle. Sua impotência e passividade são claramente refletidas na estrutura gramatical das frases. Ele não age, mas sofre os efeitos das ações. Não é ele que decide o curso dos eventos, mas o dia. Ele é conduzido cega e irresistivelmente. Raskólnikov tornou-se não aquele que molda a história, mas seu material. 
A última frase do parágrafo é uma conclusão conveniente, pois soluciona com uma metáfora as posições aparentemente contraditórias do narrador: Raskólnikov está enredado em forças além do seu controle; mas ele, não obstante, é totalmente responsável pelo assassinato. Primeiramente, a frase, mais do que qualquer outro material precedente, chama atenção para a passividade de Raskólnikov. Ele é como um homem cuja roupa está presa na roda de uma máquina. Ele também será capturado; é inevitável, a resistência será em vão. Mas ao enfatizar a passividade de Raskólnikov para desacreditar suas ilusões de grandeza, o narrador não torna seu herói uma vítima desamparada dos eventos; pois a máquina da metáfora foi feita e projetada pelo próprio Raskólnikov. É a casuística que ele usou para justificar seus planos para o crime e que removeu todas as barreiras, a não ser pelos "meros" detalhes mecânicos. Uma vez que Raskólnikov foi seduzido pelos argumentos ilusórios do racionalismo, o assassinato tornou-se não só possível, mas, de acordo com a lógica do romance, inevitável. Vistos por esta perspectiva, o tempo, lugar e modo do crime são atributos acidentais; ao passo que a casuística de Raskólnikov é sua força motora necessária. Dostoiévski, então, o retrata como uma vítima, não de forças que estão além do seu controle, mas de ideias por ele mesmo tramadas. A máquina impessoal é um símbolo da natureza mecanicista e inorgânica do intelecto racional de Raskólnikov. Ela usurpou o lugar de seu mestre, virou-se contra ele, e usou-o como uma ferramenta para satisfazer seus próprios fins. É como se ele tivesse sido tomado por uma força estranha, assim como as pessoas no sonho do epílogo. Talvez por isso, a caminho do apartamento da usurária, ele se sinta como um homem condenado à morte, e, mais tarde, confesse à Sônia que, ao matar a velha, ele matou somente a si mesmo. Embora Raskólnikov frequentemente tente culpar o destino por seu infortúnio, Dostoiévski constantemente mostra que ele é vítima somente num sentido muito especial, uma vítima que quis matar e, por isso, deve suportar toda a responsabilidade por sua própria queda.

Embora o comentário citado seja devastador, é essencialmente implícito e mesmo de baixa intensidade. O narrador faz poucas afirmações sobre Raskólnikov que sejam mais intrusas que essas. Jamais recorre ao tipo de invectiva usada na descrição de Lebeziátnikov. Além do mais, ele raramente para a narrativa para expressar suas visões sobre o herói; ao invés disso, incorpora suas observações à ação, em alguns casos, tomando uma posição tão obviamente sensata e justificada pelas circunstâncias que a falta de comentário seria provavelmente mais conspícua do que sua presença. Prova 
disso, por exemplo, é a forma pela qual ele descreve a condição de Raskólnikov imediatamente após o assassinato de Lisavieta, a meia-irmã da usurária.

O pavor se apoderava dele cada vez mais, principalmente depois desse segundo assassinato totalmente inesperado. Queria correr dali o mais rápido possível. E se nesse instante ele estivesse em condição de ver e raciocinar de modo mais correto; se pudesse ao menos perceber todas as dificuldades da situação, todo o desespero, toda a hediondez e todo o absurdo que havia nela, compreender quantas dificuldades e talvez até quanta crueldade ainda teria que superar e praticar para escapulir dali e chegar em casa - é bem possível que ele largasse tudo e dali mesmo fosse denunciar-se, e não por temer por si próprio mas pelo simples horror e repugnância pelo que havia praticado. Nele a repugnância crescia particularmente e aumentava a cada instante. Agora ele não voltaria ao baú e nem ao quarto por nada desse mundo. (p. 94)

Não é possível concordar totalmente com Pierre Hart, o qual argumenta que o narrador insere um comentário neste ponto para enfatizar o caráter repulsivo e a monstruosidade do feito de Raskólnikov ${ }^{12}$. Certamente, há sangue suficiente para tornar esse comentário supérfluo. Interromper a ação neste ponto para moralizar sobre o óbvio parece muito pouco característico do método de Dostoiévski com Raskólnikov. Nesta passagem, Raskólnikov está tão revoltado com os eventos quanto o narrador. Este diz que Raskólnikov foi incapaz, naquele momento, de ver e julgar a situação mais corretamente, mas não que ele não tivesse sido afetado por seu feito repulsivo. De fato, ele experimenta essa repugnância em muitas ocasiões, mesmo antes do crime. Aliás, esta parece ser a principal força impedindo-o de cometer o crime. Ao deixar o prédio da usurária depois da "visita-ensaio”, Raskólnikov exclama: “'Oh, Deus! Como tudo isso é repugnante! Será possível, será possível que eu... Não, isso é um absurdo, um contrasenso! - acrescentou decidido. - Será possível que tamanho horror me tenha ocorrido? Contudo, de que baixeza meu coração é capaz! O principal: isso é sórdido, nojento, abjeto, abjeto..."” (p. 26). E, em seu pesadelo da égua cruelmente espancada, Raskólnikov experimenta um terror comparável àquele que sentido no assassinato real.

\footnotetext{
12 Pierre R. Hart, "Looking over Raskol'nikov's Shoulder: The Narrator in Crime and Punishment",
} Criticism, 13 (1971), 170. 
Ele acorda do sonho gritando: "Meu Deus! [...] Será, será que eu vou pegar mesmo o machado, que eu vou bater na cabeça, vou esmigalhar o crânio dela... vou deslizar no sangue viscoso, quente, arrebentar o cadeado, roubar e tremer; esconder-me, todo banhado de sangue... com o machado... Meu Deus, será possível?” (p. 75). Essa repulsa continua muito depois do assassinato. Por isso, uma vez que os sentimentos do narrador não são essencialmente diferentes dos de Raskólnikov, seu comentário naquele ponto não parece particularmente intrusivo.

A função desta passagem, então, deve ser procurada em outra parte. Deve-se reconhecer que ela contém um comentário, mas este é daquele tipo com o qual já estamos familiarizados: de modo sutil, mas certeiro, o narrador enfraquece a exaltada autoimagem do seu herói. Raskólnikov perde totalmente o controle sobre si mesmo no momento mais crucial. Mais do que isso, suas faculdades racionais, das quais ele tanto se orgulha e as quais ele acredita irão assisti-lo com sucesso no momento do crime, ficam totalmente paralisadas. Ao repetir de modo eficaz todos os verbos de julgamento e percepção, o narrador novamente enfatiza o eclipse da razão de Raskólnikov durante o assassinato: “[...] E se nesse instante ele estivesse em condição de ver e raciocinar de modo mais correto; se pudesse ao menos perceber todas as dificuldades da situação [...] compreender quantas dificuldades e talvez até quanta crueldade ainda teria que superar e praticar para escapulir dali".

Mas essa passagem faz mais do que esvaziar as pretensões de Raskólnikov; ela funciona, paradoxalmente, como um ponto de alívio psíquico. Passamos por uma descrição de dez páginas de um assassinato e dos eventos que culminaram nele, a qual foi construída com uma intensidade quase não suavizada e impessoalidade cuidadosamente cultivada. Sem dúvida, essa impessoalidade é essencial para dramatizar os eventos no maior grau possível. Trata-se de uma das principais razões pelas quais Dostoiévski rejeitou a narração em primeira pessoa em favor de uma narração em terceira pessoa. Mas, ao mesmo tempo, essa impessoalidade contrasta marcadamente com o tom dos trechos anteriores. É como se o narrador estivesse tão mesmerizado quanto o leitor por este espetáculo tão repulsivo, como se ele não mais fosse um meio pelo qual o leitor percebesse a ação, mas um espectador como nós. A passagem é como uma irrupção de um observador que não suporta mais o horror incessante do que vê e precisa dar vazão as suas emoções. O narrador em certa medida usurpou, por assim dizer, o papel do leitor. E é precisamente por isso que não sentimos a passagem como particularmente intrusiva. De fato, ela parece perfeitamente apropriada, pois é neste 
sentido que o narrador tem nos conduzido. Seu comentário meramente dá voz aos nossos próprios julgamentos e emoções.

Embora o ponto de vista do narrador nesta passagem tenha muito em comum como o do leitor, há também muitas diferenças significativas. Já foi mencionado o sutil enfraquecimento da enfatuada autoimagem de Raskólnikov pelo narrador. Além disso, ele parece mostrar compaixão por este jovem rapaz, que ele sabe ter entrado em um processo de sofrimento, do qual o crime não passa de um estágio. "se [Raskólnikov] pudesse ao menos perceber todas as dificuldades [...] é bem possível que ele largasse tudo e dali mesmo fosse denunciar-se". Sentimos que o narrador está nos contando que Raskólnikov está violentando tanto a si mesmo quanto a sua vítima. O herói pode afirmar que não sente a menor ponta de culpa, mas ele recua com horror e repugnância diante de seu ato; é esta violência que Raskólnikov perpetra contra si mesmo e o sofrimento que ela vaticina que suscitam a compaixão do narrador.

Dostoiévski, entretanto, não restringiu o comentário narrativo sobre Raskólnikov somente ao "eu" da experiência. Se o fizesse, a obra provavelmente teria resultado mais regular, mas certamente teria sacrificado algo de sua riqueza e complexidade. $\mathrm{O}$ narrador em Crime e castigo fala não de um Raskólnikov, mas de dois: daquele que vivencia os eventos, e daquele que está separado do crime pelo tempo e por um novo mundo de experiência. As passagens de reminiscências e os comentários explícitos do epílogo nos introduzem em um âmbito temporal totalmente diferente; mudam não apenas nossa perspectiva temporal, como também nossa visão de Raskólnikov.

Ao longo do romance encontramos vinte afirmações em que o narrador alude a um tempo no qual os eventos são relembrados muito depois. Essas passagens de reminiscências variam de tamanho, conteúdo e estilo: algumas são curtas e sutilmente integradas à narrativa; outras chegam a um parágrafo inteiro e distinguem claramente passado e presente. ${ }^{13}$ Embora seja possível interpretar essas afirmações como vestígios do antigo plano de narração em primeira pessoa, um exame atento mostra que elas diferem de suas contrapartes do caderno de notas tanto na forma quanto na função.

Conforme foi ilustrado no Capítulo 2, o principal foco dos cadernos de notas está no "eu" que recorda; consequentemente, o momento da escrita é sentido de forma mais vívida do que o momento do crime. Na versão final, a situação se inverte: o passado (momento do crime) ofusca consideravelmente o momento em que

\footnotetext{
${ }^{13}$ Crime e castigo p. 28, 75, 78, 81, 89, 92, 95-6, 100, 107, 123, 131, 131, 175, 324, 360, 407, 420, 449,
} 473,520 . 
Raskólnikov olha para suas experiências anteriores, período este realmente nebuloso, que pode ser um passado mais recente, o presente ou mesmo o futuro. Além disso, os narradores são bastante diferentes: nos cadernos de notas Raskólnikov nos relata suas lembranças; na versão final essas recordações são reportadas por um narrador onisciente. A menor ênfase que a versão final concede ao Raskólnikov que recorda, entretanto, não deve nos levar a subestimar a importância dessas passagens de reminiscências, pois elas exercem um papel crucial na estrutura avaliativa e temporal do romance.

Talvez a passagem de reminiscência mais impressionante seja aquela que introduz a última parte do romance. Svidrigáilov acaba de revelar que escutou a confissão de Raskólnikov à Sônia. Os fatos pressionam. Não causa espanto que Raskólnikov se lembre de ter vivido esse período como se tivesse envolto numa névoa impenetrável. Seu encontro com Porfíri Petrovitch e Svidrigáilov somente afrouxam sua já tênue ligação com a realidade.

Para Raskólnikov começou um tempo estranho: era com se num átimo houvesse baixado uma névoa à sua frente e o encerrasse em uma solidão pesada e irremediável. Ao relembrar esse período mais tarde, muito tempo depois, ele percebia que, às vezes, era como se a sua consciência se turvasse e assim tivesse continuado, com alguns intervalos, até o desastre final. Estava positivamente convencido de que, naquele período, havia-se equivocado em muita coisa, por exemplo, na duração e no momento de alguns acontecimentos. Ao menos ao recordar mais tarde e esforçar-se por esclarecer para si mesmo o memorizado, descobria muita coisa sobre si mesmo já guiado por informações obtidas de estranhos. Confundia, por exemplo, um acontecimento com outro; considerava outro a consequência de um acontecimento que só existia na sua imaginação. Vez por outra via-se dominado por uma inquietação mórbida e torturante, que degenerava até em pavor ou pânico. Mas ele também se lembrava de que havia minutos, horas e, talvez, até dias cheios de uma apatia que se apoderava dele como se fora em contraposição ao pavor anterior - uma apatia semelhante ao estado de indiferença mórbida dos outros mortais. (p. 449, grifos nossos) 
Como as passagens em itálico indicam, o narrador insiste em fazer o leitor perceber o Raskólnikov que recorda. Ele usa diferentes formas do verbo recordar quatro vezes e deixa claro que o tempo passado se refere não ao momento dos acontecimentos, mas a um tempo em que estes são relembrados. Além disso, enfatiza que essa recordação se dá não simplesmente depois, mas "muito tempo depois" do crime: o suficiente para Raskólnikov ter se tornado um ser humano mais maduro, que tivesse aprendido com a experiência e percebido as ideias que o levaram a desencaminhar-se tanto.

Contudo, o Raskólnikov que recorda não está no mesmo plano intelectual do narrador: eles estão separados por uma considerável distância irônica. Tal distância é claramente ilustrada na seguinte passagem da Primeira Parte, na qual Raskólnikov lembra que, ao caminhar pela Praça Siénnaia, ele fica sabendo que Lisavieta, a irmã da usurária, não estaria em casa às sete horas da noite seguinte.

Mais tarde, quando rememorava esse período e tudo o que lhe aconteceu nesses dias, minuto a minuto, ponto por ponto, traço por traço, sempre o invadia uma perplexidade que chegava à superstição, devido a uma circunstância que, no fundo, embora não fosse muito incomum, depois lhe pareceu constantemente uma espécie de predestinação do seu destino. Não havia meio de entender e explicar para si mesmo porque ele, cansado, atribulado, voltou para casa pela praça Siénnaia, por onde lhe seria dispensável passar, já que era muito mais vantajoso retornar pelo caminho mais curto e direto. A volta era pequena, mais indiscutível e totalmente desnecessária. É claro que dezenas de vezes lhe acontecera voltar para a casa sem se lembrar das ruas por onde passara. Mas por que, sempre se perguntava, por que aquele encontro na Siénnaia (por onde ele não tinha nenhuma necessidade de passar), tão importante, tão decisivo para ele e ao mesmo tempo tão sumamente casual, coincida agora com essa hora, com esse minuto de sua vida, justamente com esse seu estado de ânimo e precisamente com essas circunstâncias em que só ele, o tal encontro, poderia produzir o efeito mais decisivo e mais definitivo em todo o seu destino? Como se ali estivesse de propósito à sua espera! (p. 75-6) 
O Raskólnikov mais velho obviamente ainda não compreende completamente seu crime; ele ainda parece acreditar que não foi o único autor de seu destino. A estranha combinação de circunstâncias que selaria seu destino parece-lhe ter sido préordenada. Era como se o destino tivesse-lhe preparado uma armadilha, como se toda a tragédia fosse parte de um plano elevado sobre o qual ele não exercesse qualquer controle. Essa visão do crime como uma virada do destino é mantida por Raskólnikov até o epílogo, em que o encontramos sentindo-se envergonhado, mas não culpado: "Mas ele fez um julgamento severo de si mesmo, e sua consciência obstinada não descobriu nenhuma culpa especialmente terrível no seu passado, a não ser uma simples falha que podia acontecer a qualquer um. Sentia vergonha precisamente de que ele, Raskólnikov, havia se destruído de maneira tão cega, irremediável, vaga e tola, cumprindo alguma sentença do destino cego, e devia resignar-se e submeter-se ao 'absurdo' de uma sentença se quisesse encontrar um mínimo de tranquilidade para si” (p. 553). Embora aceitemos que o Raskólnikov mais velho veja o assassinato como um crime, e não uma mera falha, ele ainda se recusa a assumir total responsabilidade por suas ações. Podemos estar certo, entretanto, que, se tudo tivesse ocorrido conforme suas expectativas, Raskólnikov teria se oposto veementemente a qualquer sugestão de que o destino, e não ele mesmo, tivesse determinado o curso dos acontecimentos.

Uma vez que sabemos que Raskólnikov não só quis, mas, em certo sentido, planejou longamente o assassinato, podemos sentir a ironia do narrador à custa mesmo do Raskólnikov mais maduro. A preocupação de Raskólnikov com a moralidade do crime e a psicologia do criminoso se prolonga por muitos meses antes da ação começar. Na Primeira Parte, Capítulo VI, ele se recorda de ter ouvido, seis meses antes, uma conversa entre um estudante e um funcionário sobre a moralidade de assassinar a velha usurária; ele também se lembra de ter ficado supersticiosamente impressionado pelo fato de ter acabado de retornar do apartamento desta mesma velha exatamente com a mesma ideia. Embora pareça que Raskólnikov tenha escolhido sua vítima somente um mês e meio antes do início do romance, sabemos que a justificativa moral para o crime contemplado estava estabelecida num artigo que ele terminou antes de deixar a universidade - seis meses antes do crime. E ainda mais impressionante é a confissão de Raskólnikov à Dúnia de ter explicado todas as suas ideias a sua antiga noiva, cuja morte data de mais de um ano antes dos eventos do romance.

Mesmo que os acontecimentos ao redor do crime não passem de coincidência, o próprio assassinato era inevitável. Se não fosse Aliona Ivanovna, teria sido outra pessoa. 
Mais um mês trancado naquele sótão, faminto, deprimido e febril, Raskólnikov teria afiado tanto sua casuística a ponto de racionalizar o assassinato de alguém muito menos repulsivo física e moralmente do que a velha usurária. Não espanta que haja uma ponta de ironia na afirmação do narrador de que Raskólnikov acreditava que um incidente, embora não muito incomum, tivesse determinado seu destino.

O narrador também alude a reminiscências de outros personagens. Embora estas não sejam tratadas com a mesma ironia que as de Raskólnikov, parecem cobrir o mesmo período. Por exemplo, Razumíkhin lembra-se por toda a vida do momento no corredor em que Raskólnikov o encarrega de cuidar de sua mãe e irmã. Zamiétov recorda a estranheza do seu encontro com Raskólnikov no Palácio de Cristal e Sônia lembra-se do momento em que Raskólnikov confessa pela primeira vez ter assassinado Lisavieta: "Até mesmo depois, mais tarde, quando ela recordava esse instante, sentia-se estranha e maravilhada: por que naquela ocasião justamente ela percebera de forma tão imediata que já não havia quaisquer dúvidas?” (p. 420). Expressa quase exatamente como a de Raskólnikov, a recordação de Sônia projeta sua vida tão longe no futuro quanto a dele. Mais do que isso: a própria aplicabilidade do mesmo sistema temporal a Sônia e outros personagens garante sua realidade objetiva para o romance como um todo. Não se trata de um mero instrumento para enfatizar a confusão do Raskólnikov da experiência, mas uma parte integral da estrutura retórica do romance.

Essas passagens de reminiscência podem, de fato, indicar que o texto é uma confissão, conforme relatada a uma terceira pessoa. Tomemos, por exemplo, um breve trecho de reminiscência que introduz a cena na qual o camponês Nicolai aparece diante de Porfíri e Raskólnikov e confessa ter cometido o crime: "Mais tarde, ao rememorar esse instante, Raskólnikov viu toda a cena da seguinte maneira” (p. 360). Podemos, a partir dessa afirmação, concluir que o narrador seja, talvez, um escritor para quem um Raskólnikov regenerado tenha reportado todas as suas experiências e o autorizado a escrever sua biografia como lição para outros? Seria Crime e castigo uma tentativa inicial de Dostoiévski em escrever a primeira parte de seu estimado projeto A vida de um grande pecador? As amplas implicações dessa visão são, de fato, intrigantes, e é certamente uma área que exige mais estudos.

Além de projetarem os eventos para longe do escopo do romance, as passagens de reminiscências prefiguram o epílogo, que, por sua vez, torna explícita as implicações das lembranças de Raskólnikov. Assim, juntamente com o epílogo, elas formam um sistema temporal coerente e irônico que atravessa todo o romance e responde suas 
questões implícitas: Qual o destino de Raskólnikov? Haverá alguma esperança para aqueles que foram corrompidos pelo orgulho e as heresias racionalistas do Ocidente? Raskólnikov, ao fim e ao cabo, é mais do que um assassino isolado ou mesmo um tipo social; ele é o símbolo de um estágio na vida espiritual e intelectual do desenvolvimento do homem. Ele é a tentativa mais bem sucedida de Dostoiévski de construir, não um super-homem, mas um homem comum.

A relação entre o epílogo e as passagens de reminiscências é complexa. Embora sejamos informados logo no começo de que o herói está recordando os acontecimentos muito depois de sua ocorrência, apenas gradualmente percebemos que tais passagens levam-nos muito além do tempo do epílogo, em direção a um âmbito temporal nebuloso, que o narrador diz pertencer a uma outra história. Portanto, elas pressupõem não só a prisão de Raskólnikov, mas, também, o longo processo de regeneração. Não obstante, este processo está longe de completar-se. O Raskólnikov que recorda ainda não possui a percepção do narrador sobre o crime e suas causas; pois esse conhecimento só poderá vir depois dos vários anos de sofrimento profetizados pelo narrador na última página do epílogo.

A regeneração de Raskólnikov, certamente, não está explícita nas passagens de reminiscências; está implícita e só pode ser percebida no conjunto com outras cenas e afirmações do romance. E isso dificilmente poderia ser diferente. Insistir na ressurreição de Raskólnikov nas passagens de reminiscências reduziria o suspense psicológico e destruiria o efeito da conversão miraculosa, e até inesperada, do epílogo. Entretanto, se tomadas junto com certos acontecimentos e cenas, as passagens de reminiscências formam um esboço mais do que sugestivo do destino de Raskólnikov, a tal ponto óbvio que torna o epílogo um sumário - como provavelmente foi planejado - e não um choque. Conhecemos os traços religiosos de Raskólnikov: suas orações quando criança, seu sentimento inexplicável diante da catedral de São Isaac, sua crença literal na Nova Jerusalém e seu desejo de ouvir a passagem da ressurreição de Lázaro. Também testemunhamos sua necessidade compulsiva de confessar, ou mesmo expiar, seu crime: seu desmaio na delegacia, seu desafio aos pintores no apartamento de Aliona Ivanovna; suas revelações à Sônia e, finalmente, sua confissão a Iliá Petrovitch. Também estamos cientes todo o tempo do quase alegórico papel da salvadora de Raskólnikov, Sônia Marmieládov, e sentimos que seu esforço não será vão. Essas cenas dão substância para as vagas insinuações contidas nas reminiscências do futuro de Raskólnikov. Mas o efeito é recíproco. Visto em termos da perspectiva temporal dupla criada pelas 
passagens de reminiscências, todo o simbolismo, fatos e episódios que indicam a transformação de Raskólnikov no epílogo adquirem maior credibilidade artística. O simples fato de sabermos que o Raskólnikov que recorda é significativamente diferente daquele que vivencia faz com que a esperança que Sônia sustenta em relação a ele seja seriamente considerada pelo leitor. Nossas sensibilidades estão preparadas, ao menos levemente, para o renascimento de Raskólnikov no epílogo.

Se a principal função das passagens de reminiscências é prefigurar o epílogo, qual será então a função do epílogo propriamente dito? Será apenas a de confirmar nossas intuições, ou ele acrescenta algo à nossa compreensão da personalidade de Raskólnikov e das implicações do seu destino? E quão importante é o papel do narrador no epílogo? O que, por exemplo, ele faz no epílogo que deixa de fazer antes no romance? A maioria dos críticos tem demonstrado, compreensivelmente, pouca preocupação pelo narrador no epílogo; em geral, eles mostram-se insatisfeitos com os fatos em si, e, consequentemente, sentem pouca necessidade de examinar como eles são $\operatorname{apresentados}^{14}$. A maioria dos críticos obviamente se opõe à "falha" de Dostoiévski em não apresentar a conversão de Raskólnikov de modo detalhado e psicológico, como fizera com o plano do crime, sua execução e a provação subsequente. Mas, considerando que uma conversão miraculosa dificilmente pode ser representada assim, o que os críticos do epílogo estão, de fato, dizendo é que a própria conversão carece de

\footnotetext{
${ }^{14}$ Não conheço nenhum crítico soviético que tenha considerado o epílogo artisticamente satisfatório. Críticos ocidentais tampouco ficaram particularmente contentes com ele. Cf., por exemplo, John Middleton Murry, Fyodor Dostoevsky: A Critical Study (Londres: Martin Secker, 1923), pp. 122-3; Julius Meier-Graefe, Dostoevsky: The Man and His Work, trad. Herbert H. Marks (Nova Iorque: Harcourt, 1928), pp. 134-8; Ernest J. Simmons, Dostoevsky: The Making of a Novelist (1940; reedição Londres: John Lehmann, 1950), pp. 152-5. Konstantin Mochulsky, Dostoevsky: His Life and Work, trad. Michael A. Minihan (Princeton: Princeton University Press, 1967), p. 312, embora um adepto da antropologia cristã de Dostoiévski, considera o epílogo uma "mentira devota". Há também aqueles que acreditam que todos os epílogos são artisticamente inadequados. V. B. Chklovski, Povesti o proze: Razmichlenia $i$ razbori (M.: GIXL, 1966), II, 220-1, sustenta que os romancistas usam epílogos por serem incapazes de completar suas histórias adequadamente. Joseph Warren Beach, The Twentieth Century Novel: Studies in Technique (Nova Iorque: Appleton, 1932), p. 249, afirma que "o leitor do século XX não aprecia esse tratamento esboçado [do epílogo] de acontecimentos futuros, ele não se importa em saber como cada personagem recebeu a devida recompensa por sua vida virtuosa. Ele gosta de um desfecho claro e definitivo." As observações do narrador em A aldeia Stepantchikovo sobre o epílogo desta obra indicam que Dostoiévski estava bastante consciente das armadilhas dos epílogos, e, portanto, podemos supor que ele teve boas razões para incluí-lo em suas duas maiores obras, Crime e castigo e Os irmãos Karamázov. "A novela chega ao seu término. Os noivos se casaram, e o gênio do Bem impera como senhor absoluto na casa, encarnado na pessoa de Fomá Fomitch. Poderíamos, ao chegar aqui, espraiamo-nos em explicações; mas realmente, todo esclarecimento será demais. Pelo menos essa é a minha opinião. Em lugar das aludidas explicações, ainda direi umas palavras acerca da sorte ulterior de todos os heróis de meu relato: sem esse pormenor, sabe-se, não se pode dar como concluída nenhuma novela, pois assim o ordenam os cânones” (Dostoiévski, F. M. Noites Brancas e Outras Histórias. Trad. Olívia Krähenbül. Rio de Janeiro: José Olympio, 1960).
} 
verossimilhança: é implausível que o orgulhoso e desconfiado Raskólnikov do romance pudesse sofrer tamanha virada, apesar mesmo de Sônia Marmieládova.

Em resposta a tal crítica, eu apontei, neste e nos capítulos anteriores, alguns dispositivos estruturais, senão psicológicos, que Dostoiévski usa para motivar o epílogo. Cenas, fatos e afirmações desde o princípio prefiguram os eventos vindouros. Nesta seção a discussão será restrita às diferenças na estrutura narrativa do epílogo e do romance, de modo a esclarecer os laços orgânicos entre ambos, particularmente na natureza da transição de Raskólnikov de uma velha para uma nova vida.

Os comentários narrativos do primeiro e de metade do segundo capítulos do epílogo diferem pouco daqueles do romance. No primeiro capítulo o narrador descreve o julgamento de Raskólnikov e relata em ordem cronológica: Sônia o acompanha à Sibéria, Dúnia e Razumíkhin se casam, Pulkhéria enlouquece e morre. Assim como no romance, o narrador vez por outra trata seu material com variados graus de ironia. $\mathrm{O}$ julgamento de Raskólnikov é um bom exemplo. Embora gostasse de assistir a julgamentos, especialmente aqueles que envolviam assassinato, Dostoiévski permaneceu a vida toda cético em relação ao sistema jurídico ocidental, que se estabelecera na Rússia em consequência das grandes reformas de 1864. Tal ceticismo certamente foi expresso com todo vigor no gênio satírico de Dostoiévski na última parte de Os irmãos Karamázov, mas também está presente em seu tratamento das tentativas por parte dos juízes e advogados de entender o crime de Raskólnikov.

Por último, alguns (particularmente os psicólogos) admitiram até a possibilidade de que ele realmente não tivesse examinado a bolsa e por isso mesmo não sabia o que havia nela e, sem saber, acabou metendo-a debaixo da pedra, mas daí mesmo concluíram que o próprio crime não podia haver sido cometido senão em algum estado momentâneo de loucura, por assim dizer, de monomania mórbida de assassinato e saque, sem outros fins e cálculos de vantagem. Aqui, a propósito, veio a calhar a moderna teoria em moda sobre a loucura momentânea, que atualmente se procura aplicar com frequência a outros criminosos. (p. 544)

A ironia do narrador é evidente. A loucura momentânea, pelo menos do ponto de vista psicológico, parece uma explicação superficial para as complexas atitudes mentais que levaram ao crime - trata-se de uma teoria em moda, uma abstração, e, por esta 
natureza mesma, incapaz de descrever com precisão um processo vivo. Além disso, Raskólnikov não estava momentaneamente louco, a menos que se argumente que todos os homens que cometem assassinatos estão loucos no momento do crime. Se, por outro lado, a insanidade for tomada como uma visão distorcida da realidade, então Raskólnikov deve ser considerado louco, não momentaneamente, mas ao longo de quase todo o romance. Os psicólogos são capazes de categorizar o caso de Raskólnikov com base na evidência menos substancial, ao passo que o romancista, mesmo com acesso direto à consciência do herói, deixou a motivação - pelo menos em seu aspecto puramente psicológico - essencialmente não resolvida. O narrador também descarta o modo pelo qual os psicólogos chegam à sua teoria: eles interpretam o fato de Raskólnikov não olhar a bolsa como uma prova de que ele não estava totalmente em posse de suas faculdades, como se o assassinato por si só não fornecesse razões suficientes. E, ainda assim, é compreensível que eles cheguem a conclusões tão superficiais; afinal, eles não possuem qualquer conhecimento real das motivações de Raskólnikov: ele não matou para roubar, mas roubou para matar.

Embora comentários narrativos estejam presentes ao longo de toda descrição do julgamento, eles são relativamente inconspícuos. Não diferem significativamente das formas mais sutis de ironia do romance. Além disso, há poucos comentários no restante do capítulo. A maior parte do reportado pelo narrador sobre Razumíkhin, Dúnia, Pulkhéria Alexandrovna, Sônia e Raskólnikov é factual. Ele mostra alguma compaixão pela demência de Pulkhéria e apresenta as ações de Dúnia, Razumíkhin e Sônia em uma chave positiva, mas não mais do que nos capítulos anteriores. De fato, os sumários aqui são dos menos avaliativos do romance.

A primeira metade do capítulo II também é como o restante do romance em relação aos comentários. O narrador nos fala longamente sobre Raskólnikov, mas geralmente abstém-se de censurá-lo abertamente. Somos informados de que ele inicialmente não se adapta à vida na colônia penal, mas este fato poderia ser confirmado por qualquer um da prisão. Ainda assim, a frequente crítica do narrador pode ser percebida. Ao transcrever ostensivamente somente a consciência, ele constantemente ataca a imagem enfatuada do herói sobre sua autoflagelação:

Há muito ele andava doente; mas não eram os horrores da vida de galé, nem o trabalho, nem a comida, nem a cabeça raspada, nem o uniforme de retalhos que o quebrava: oh! que lhe importavam todos esses sofrimentos 
e torturas! Ao contrário, ele estava até contente com o trabalho: exaurido fisicamente pelo trabalho, ao menos conseguia algumas horas de sono tranquilo. E que significava a comida para ele - essas sopas de repolho sem nada e com baratas? Frequentemente nem isso tinha antes, quando era estudante. A roupa agasalhava e estava adaptada ao seu modo de vida. Os grilhões ele nem chegava a sentir em seu corpo. Iria envergonhar-se da cabeça raspada e da meia jaqueta? Diante de quem? De Sônia? Sônia o temia, e era dela que ele iria sentir vergonha?

Então o que era? Ele sentia vergonha até de Sônia, que ele atormentava com o tratamento desdenhoso e grosseiro que lhe dispensava. (p. 553)

Os elementos do discurso oral - a imodéstia, exclamações, e perguntas retóricas - todos indicam tratar-se de consciência narrada. Apesar das humilhações e privações da vida na prisão, Raskólnikov ainda é o mesmo homem. Os grilhões, ao fim e ao cabo, não podem aniquilar seu espírito ou golpear sua exaltada autoimagem; já que ele afirmou a Porfíri que "o sofrimento e a dor são sempre obrigatórios para uma consciência ampla e um coração profundo" e que "os homens verdadeiramente grandes [...] devem experimentar uma grande tristeza no mundo" (p. 273-4)

Ainda que a passagem seja relatada do ponto de vista de Raskólnikov, a presença do narrador é discernível, arremedando Raskólnikov com vistas a obter efeito irônico. A negação das privações e degradações da vida na prisão é convencimento orgulhoso. Ele finge não envergonhar-se de sua cabeça raspada ou de sua roupa em retalhos; mas, como o narrador perspicazmente aponta, numa afirmação que coloca todo o precedente em chave irônica, Raskólnikov estava envergonhado até mesmo diante de Sônia, e a torturava por estar consciente disso. O uso desta técnica no epílogo indica que mesmo nesse ponto o herói não sofreu nenhuma mudança significativa. Ironia sutil e mordaz continua sendo a forma mais apropriada para o ainda impenitente $\mathrm{e}$ infinitamente orgulhoso Raskólnikov.

Em algumas passagens posteriores, o narrador aumenta sua distância em relação ao protagonista, apresentando os pensamentos deste em monólogo interior. Raskólnikov permanece impenitente e, mais do que nunca, convencido de estar perecendo sem razão; de que seu feito é criminoso somente sob a perspectiva legal, e, ainda, somente por não ter sido coroado com sucesso. Ele acredita, como antes, que o poder faz a razão: "No entanto, aqueles homens aguentaram os seus passos e por isso estavam certos, mas eu 
não aguentei e, portanto, não tinha o direito de me permitir esse passo" (p. 554). Assim como na passagem anterior, o narrador imediatamente rebaixa a posição do herói depois de transcrever seus pensamentos: "Eis em que ele não reconhecia seu crime: apenas no fato de não o ter aguentado e ter confessado a culpa" (p. 554). Novamente, o narrador condena a desvirtuada escala de valores de Raskólnikov. Para enfatizar ainda mais a crítica do narrador, Dostoiévski destaca o breve comentário fazendo dele um parágrafo independente. Trata-se de um comentário indubitavelmente forte, mas está longe de ser raro. O narrador trata Raskólnikov da mesma forma no restante do romance.

Na segunda página deste último capítulo (na verdade, imediatamente depois da observação do narrador discutida acima) há uma passagem de ordem totalmente distinta.

Ele sofria também ao pensar: por que não se matara naquele momento? Por que ficou parado acima do rio e preferiu confessar sua culpa? Será que existe tamanha força nesse desejo de viver e é tão difícil superá-lo? Svidrigáilov, que tinha medo de morrer, não o superou?

Ele se fazia essa pergunta atormentado, e não conseguia entender que, naquele momento em que estava sobre o rio, talvez pressentisse uma profunda mentira no seu íntimo e em suas convicções. Não compreendia que aquele pressentimento pudesse ser o prenúncio da futura transformação em sua vida, de sua futura ressurreição, da sua futura concepção nova de vida. (p. 554)

Primeiro o narrador nos conta que o início do renascimento de Raskólnikov e sua concepção nova da vida já estavam presentes muito antes da confissão do crime. Mas mesmo aqui ele não é completamente explícito; ele não diz que Raskólnikov "pressentiu" a falsidade em si mesmo, mas "talvez [a] pressentisse". Entretanto, essa reserva é, de certa forma, neutralizada pela afirmação seguinte, em que o narrador fala explicitamente sobre a ressurreição e a nova vida - motivo dominante das últimas páginas do epílogo. Não apenas o conteúdo, mas o tom é inteiramente diferente do que vimos antes. Sentimos imediatamente que a ressurreição de Raskólnikov e sua nova concepção da vida representam uma dramática mudança para melhor. Pode-se argumentar que as referências do narrador ao renascimento de Raskólnikov não passam de fatos, não constituindo comentários explícitos, mas poucos deixariam de notar a aprovação no tom do narrador e a crítica que a palavra $l o j$ - que em russo combina o 
significado de "falsidade" e a força de "mentira" - imprime sobre as convicções anteriores de Raskólnikov.

Nas duas últimas páginas do romance, contudo, o comentário se torna perfeitamente explícito. É como se o narrador não sentisse mais necessidade de esconder, mesmo parcialmente, seus sentimentos sobre a perspectiva modificada de Raskólnikov. Novamente o tema da ressurreição ressoa: "Eles queriam falar mas não conseguiram. As lágrimas estavam em seus olhos. Os dois eram pálidos e magros; mas nesses rostos doentes e pálidos já raiava a aurora de um futuro renovado, pleno de ressurreição e vida nova. O amor os ressuscitara, o coração de um continha fontes infinitas de vida para o coração do outro.” (p. 559). O surpreendente aqui não é o que é dito, mas quem o diz. O narrador não mostra sua aprovação dessas ideias de forma tão explícita desde a cena em que Sônia lê a passagem sobre Lázaro. Mas esse trecho é muito mais que um eco; ele confere a essa cena um sentido de conclusão, de profecia realizada. As esperanças mais acalentadas de Sônia se realizaram; além disso, os argumentos de Raskólnikov contra sua fé em Deus foram esmagados quando ele tenta considerar seu ponto de vista. A ressurreição de Lázaro se tornou uma realidade vital para a Petersburgo do século XIX, e, por conseguinte, para todos os tempos.

O narrador parece exultar com a ressurreição de Raskólnikov, assim como havia mostrado afinidade com fé de Sônia na leitura da passagem sobre Lázaro; igualmente nesta cena, o tom é perfeitamente harmonizado com a mensagem: é completamente desprovido da ironia com a qual Raskólnikov é tratado ao longo do romance. Se a passagem de Lázaro prefigura essas afirmações explícitas do epílogo, elas, por sua vez, conferem às profecias anteriores maior credibilidade artística.

O comentário mais franco do narrador sobre Raskólnikov aparece na última página do epílogo. Aqui ele toma o partido da emoção e do sentimento em detrimento da lógica estéril: a aprovação aberta do novo Raskólnikov é evidente em cada palavra.

\footnotetext{
Aliás, nessa noite ele não conseguia pensar de forma demorada e constante em nada, concentrar o pensamento em nada; demais, agora ele não resolveria nada de modo consciente; apenas sentia. A dialética dera lugar à vida, e na consciência devia elaborar-se algo inteiramente diferente. [...] Ele não sabia nem que essa nova vida não lhe sairia de graça, que ainda deveria pagar caro por ela, pagar por ela com um grande feito no futuro... (p. 559-61)
} 
Esse tipo de comentário sobre Raskólnikov naturalmente levanta questões sobre o julgamento artístico de Dostoiévski. Teria ele falhado em perceber a inadequação de tal elogio; ou seria esse um artifício com função não menos importante do que os comentários sutis e, em sua maioria, implícitos do romance? Um exame atento do texto mostra que a mudança no tratamento do narrador em relação à Raskólnikov se encaixa perfeitamente na função do epílogo.

Embora haja poucos trabalhos teóricos sobre o epílogo como dispositivo narrativo, considera-se, em geral, que ele não deva ser estruturalmente necessário à história. Na prática, a função da maioria dos epílogos é tornar explícito aquilo que no romance tenha sido somente sugerido. Mas o epílogo não é somente uma conclusão explicativa, é uma conclusão que difere do romance tanto tonal quanto estruturalmente; pois tudo nele é elaborado para conferir uma nota de finalidade e um senso de resolução àquilo que precede. Também funciona como garantia de que aquilo que estava sugerido no romance não seja mal compreendido - alguns podem até dizer, e têm dito sobre Crime e castigo, que é uma concessão para leitores menos perceptivos ${ }^{15}$. Em todo caso, trata-se do momento em que todas as coisas se tornem evidentes, e, nesse sentido, o epílogo de Crime e castigo não é uma exceção.

Talvez a característica estilística mais notável do epílogo que o distingue do romance é a preponderância do sumário. Enquanto a maioria das cenas do romance é concebida dramaticamente, o epílogo é, em grande medida, dedicado a reportar o que acontece depois que Raskólnikov entrega-se para a polícia. Embora contenha uma quantidade considerável de discurso narrado e mesmo uma passagem de monólogo interior, ele inclui somente três linhas de diálogo, o que talvez explique porque os leitores sentiram que o epílogo difere tão radicalmente de tudo que o precede. O uso intenso do sumário no epílogo é deliberado: é a única forma de o narrador poder atualizar de modo conciso as histórias dos personagens principais, especialmente daqueles cujo destino é importante para a estrutura temática do romance. Aqui também o epílogo não traz surpresas, mas torna explícito o que estava sugerido no romance: Sônia segue Raskólnikov para Sibéria e se torna instrumento de sua ressurreição; Dúnia e Razumíkhin se casam e Pulkhéria Alexandrovna morre sofrendo pelo filho.

\footnotetext{
${ }^{15}$ Simmons, p. 152; Mochulsky, p. 312.
} 
A estrutura temporal do epílogo também é afetada pela técnica do sumário. Enquanto as seis primeiras partes do romance levam apenas doze dias, o epílogo (que corresponde a aproximadamente um quinto do romance) leva mais de nove meses evidentemente o suficiente para Raskólnikov renascer. O ritmo do epílogo é lento; os eventos não são amontoados como frequentemente o são no romance. Há longos períodos sobre os quais não sabemos nada. Enquanto, no romance, Dostoiévski constantemente nos lembra a hora e local exatos dos acontecimentos, no epílogo somos introduzidos num domínio temporal especial que tende mais para as verdades da Bíblia do que para as realidades existenciais da vida nas favelas da Petersburgo oitocentista: “Ali havia liberdade e vivia outra gente, em nada parecida à de cá, lá era como se o próprio tempo houvesse parado, como se ainda não tivessem passado o século de Abraão e o seu rebanho.” (p. 558)

A apresentação da psicologia de Raskólnikov no epílogo também contrasta nitidamente com aquela do romance. O primeiro capítulo mal chega a mencioná-la. Em sua maior parte trata de Razumíkhin, Dúnia e Pulkhéria Alexandrovna, e os trechos que tratam de Raskólnikov apresentam somente seu comportamento exterior. A descrição do narrador sobre o julgamento, por exemplo, foca o processo judicial e não a psicologia do acusado; e nosso conhecimento sobre os primeiros dias de Raskólnikov na prisão é restrito às cartas de Sônia, que, como o narrador diz: "estavam repletas da realidade mais corriqueira, da descrição mais simples e clara de todo o ambiente da vida de galé de Raskólnikov [...] havia apenas fatos, ou seja, as próprias palavras dele, notícias detalhadas sobre seu estado de saúde" (p. 550).

O capítulo final, excetuando-se as primeiras páginas, trata a psicologia de Raskólnikov somente em termos gerais, contrastando claramente com o restante do romance, no qual cada ato e pensamento do herói são submetidos a uma detalhada análise interior. Neste último capítulo o narrador sintetiza as observações de Raskólnikov sobre a vida na prisão e o comportamento de seus companheiros, mas nos diz pouco sobre suas experiências internas.

A conclusão contém um sonho que também difere significativamente dos outros. Em primeiro lugar, não se trata de um sonho experimental - de fato, Raskólnikov nem participa dele ${ }^{16}$. Enquanto os outros sonhos são bastante vívidos e sutilmente integrados

\footnotetext{
${ }^{16}$ Para uma discussão sobre as diferenças entre os sonhos de Raskólnikov no epílogo e os outros quatro do romance, ver J. Thomas Shaw, "Raskol'nikov's Dreams", Slavic and East European Journal, 17
} 
ao romance - a ponto de o leitor frequentemente sentir que está vivenciando, não um sonho, mas a própria realidade -, o sonho do epílogo é uma recordação. Além disso, não é apenas um sonho, mas uma composição de uma quantidade não especificada de sonhos que presumivelmente têm conteúdo quase idêntico. Assim como muito do material do epílogo, trata-se de um sumário, mas de um tipo muito especial; pois representa a afirmação mais explícita do narrador sobre as causas da doença e do crime de Raskólnikov. Ele tornou-se vítima do racionalismo, uma doença infecciosa, que eventualmente resulta na morte de quase todos, exceto de algumas almas puras, cujo destino é construir uma nova raça humana. Desse modo, o sonho revela a ideologia subjacente a Crime e castigo, e, como tal, preenche a função primordial do epílogo: explicitar todas as implicações do romance.

O restante do capítulo relata os sentimentos de Raskólnikov de esperança renovada - um estado psicológico que, certamente, vem à tona somente no epílogo.

Ademais, o que significavam todos esses, todos os suplícios do passado? Tudo, até o crime dele, até a condenação e o exílio, agora, no primeiro impulso, pareciam-lhe algum fato externo, estranho, até como se não tivesse acontecido com ele. [...] A dialética dera lugar à vida [...] Mas aqui já começa outra história, a história de renovação gradual de um homem, a história do seu paulatino renascimento, da passagem progressiva de um mundo a outro, do conhecimento de uma realidade nova, até então totalmente desconhecida. Isto poderia ser o tema de um novo relato - mas este está concluído. (p. 559-61)

Esta, certamente, não é mais a psicologia do velho Raskólnikov impenitente; ela tampouco é apresentada da mesma forma. O narrador diz que Raskólnikov é um novo homem, e o afirma com evidente aprovação. A mudança na técnica corresponde à mudança no próprio Raskólnikov. Mas ela não é abrupta, improvável ou insuficientemente motivada, mesmo de um ponto de vista psicológico, como os críticos tentaram fazer crer. A crítica de que o lado religioso de Raskólnikov não é suficientemente desenvolvido no romance deixa de considerar que tais traços religiosos

(1973), 139-44. [Ainda sobre esse assunto, cf. Katz, M. Dreams and the unconscious in nineteenth century Russian fiction. Hanover and London: University Press of New England, 1984. - N. da T.] 
devem ser latentes. Caso contrário, ele jamais teria entrado num caminho de tamanha destruição.

O fato de esses traços serem latentes não significa, contudo, que eles não sejam vigorosamente sugeridos e em alguns casos dramaticamente representados. Cenas como o sonho da infância de Raskólnikov, o desejo de ouvir a passagem sobre a ressurreição de Lázaro, e sua crença literal na Nova Jerusalém, todos esses exemplos constituem o outro lado de sua personalidade; e não teriam sentido de outro modo.

Os detratores do epílogo também deixaram de perceber que a miraculosa conversão de Raskólnikov deve ser compreendida tanto em termos metafísicos como práticos $^{17}$. Ele não se transforma em um santo no epílogo. No máximo, a direção de sua vida foi modificada. De uma perspectiva metafísica, trata-se realmente de um milagre e uma justificativa suficiente para considerar Raskólnikov um novo homem; mas em termos práticos, ele está longe de uma recuperação completa, a qual, como o narrador afirma explicitamente, pertence a um futuro distante e pela qual ele pagará caro. $\mathrm{O}$ sentimento de Raskólnikov de uma nova vida manifesta-se mais claramente em sua apreciação de Sônia, que pacientemente o viu passar por muitas crises sem pressioná-lo indevidamente com a religião. É incorreto chamar esse renascimento no epílogo de conversão religiosa, pois ele não troca suas visões ateístas pela ortodoxia de Sônia, mas começa a viver de modo emocional, ao invés de analítico. "Será que agora as convicções dela podem não ser também as minhas convicções? Os seus sentimentos, as suas aspirações, ao menos..." (p. 561). A expressão “ao menos” indica que Raskólnikov descarta a possibilidade de aceitar imediatamente as visões religiosas de Sônia. Ao invés disso, pergunta se poderá compartilhar seus sentimentos, especialmente seu grande amor e devoção e suas aspirações, sua esperança pela felicidade futura deles. Se Raskólnikov poderá algum dia aceitar as crenças de Sônia é uma questão que o narrador relegou a outro tempo e lugar - e a outra história. Raskólnikov está simbolicamente reformado no epílogo, mas, em termos mundanos, como afirma o narrador, sua renovação será lenta e gradual, poderia constituir um novo relato, que requereria uma apresentação detalhada da psicologia de Raskólnikov, tão característica do romance.

Poderíamos, certamente, aceitar os eventos do epílogo e ainda assim ter reservas sobre a forma como eles são apresentados. A aprovação quase extasiada do novo caminho que Raskólnikov inicia pode constituir, para alguns leitores, um choque maior

\footnotetext{
${ }^{17}$ Para uma interessante discussão sobre a natureza da conversão de Raskólnikov no epílogo, ver A. Boyce Gibson, The religion of Dostoevsky (Londres: SCM Press Limited, 1973), pp. 88-103.
} 
do que sua própria renovação. Mas, se o epílogo serve para esclarecer aquilo que no romance aparece principalmente de modo implícito, então os comentários explícitos e francamente expressos tornam-se não só apropriados, mas essenciais.

\section{Capítulo 10 - O PONTO DE VISTA ELEVADO}

Os últimos capítulos, em que foram enfocados os vários métodos usados pelo narrador para influenciar o julgamento do leitor sobre os personagens e acontecimentos, não foram construídos para demonstrar que Crime e castigo é relatado de modo mais subjetivo do que a maioria dos romances escritos no mesmo período. Mesmo se a objetividade for definida como a ausência de um narrador que faz generalizações acerca da vida e que comenta os méritos e fraquezas de seus personagens, Crime e castigo deve ainda ser considerado um dos romances mais objetivos da segunda metade do século XIX.

Embora Dostoiévski não despersonalize seu narrador, nem reduza sua função à transcrição da consciência, ele, em geral, deixa a estória contar-se a si mesma. A narração em terceira pessoa acelera significativamente o fluxo dos eventos, enquanto que a ampla utilização de consciência narrada e monólogo interior conferem uma aura objetiva à apresentação que o narrador faz da psicologia de Raskólnikov. Além disso, a grande quantidade de diálogos no romance oferece-lhe, em certa medida, a aparência e sensação de uma verdadeira peça teatral ${ }^{18}$. Como diria Percy Lubbock, ao fazer-nos suspender nossa descrença, Dostoiévski nos obriga a encarar sua história como algo mostrado, não contado.

De fato, basta comparar Crime e castigo com os romances mais proeminentes escritos no mesmo período para ver quão objetivo ele é para a época. É certamente mais objetivo que os romances de Dickens, Balzac e George Eliot. Tolstói e Turguêniev, os maiores rivais de Dostoiévski em seu país, não escreveram romances tão "impessoais" quanto Crime e castigo. Mesmo em Madame Bovary de Flaubert, muito elogiado por sua objetividade, emprega um narrador mais subjetivo e pessoal. Embora o narrador de

\footnotetext{
${ }^{18}$ Essa é a tese central do texto pré-revolucionário de Viatcheslav Ivánov, Freedom and Tragic Life: A Study in Dostoevsky, tradução Norman Cameron (Nova Iorque: Noonday, 1957). Nos últimos doze anos esse texto tornou-se amplamente aceito na União Soviética, com indubitável influência da segunda edição de Problemas da Poética de Dostoiévski (1963) de M. M. Bakhtin, embora sua tese tenha sido apresentada praticamente da mesma forma que na primeira edição do livro (de 1929).
} 
Crime e castigo por vezes se permita fazer generalizações filosóficas, ele o faz muito menos frequentemente do que sua contraparte de Madame Bovary. Esses romances diferem também no tratamento da vida interior dos personagens, especialmente na transcrição da consciência. Em Crime e castigo, os sentimentos e pensamentos dos personagens são, no todo, registrados em sua própria linguagem. Em Madame Bovary, por sua vez, o estilo polido da prosa do narrador se revela sempre que são transcritas as mentes vulgares de Carlos e Emma.

Pode-se argumentar que a transcrição da consciência parece mais objetiva em Crime e castigo porque os personagens são articulados e próximos do nível intelectual do narrador. A objetividade de alguns romances de Henry James, por exemplo, tem mais relação com a semelhança entre as sensibilidades do narrador e dos personagens do que com a inteligência central de James. Mas a linguagem do narrador em Madame Bovary vai muito além de uma representação neutra do psiquismo dos personagens; de fato, às vezes ela se envolve em metáforas elaboradas, estranhamente incompatíveis com as sensações e pensamentos que deve transmitir. O método metafórico de transcrição da consciência, como vimos, também está presente em Crime e castigo; mas ele é utilizado somente aqui e ali. A seguinte passagem, que mostra a crescente desilusão de Emma com Carlos, é típica do método de Flaubert para apresentar os pensamentos de Emma.

Se, entretanto, Carlos quisesse, se ele suspeitasse de semelhante coisa, se o seu olhar, uma única vez, fosse ao encontro do seu pensamento, talvez que uma súbita riqueza se lhe destacasse do coração, como caem os frutos de uma árvore que se sacode. Mas, à proporção que mais se apertava a intimidade da sua vida, mais aumentava essa espécie de desapego interior que a desligava dele.

A conversa de Carlos era plana como o passeio da rua, e as ideias de toda a gente desfilavam nela com o seu feitio vulgar, sem provocar como cão, riso ou devaneio. Carlos nunca tivera curiosidade, dizia ele, enquanto residia em Ruão, de ir ao teatro ver os atores de Paris. Não sabia nada, nem esgrimir, nem atirar, e não pôde um dia explicar-lhe certo termo de equitação que ela encontrara num romance (p. 37) ${ }^{19}$

\footnotetext{
${ }^{19}$ Para citação foi utilizada a seguinte edição em português: FLAUBERT, Gustave. Madame Bovary. Trad. Araújo Nabuco. São Paulo: Abril Cultural, 1970. (N. da T.)
} 
Emma se sente traída: ela pensou que, ao menos no casamento, seus sonhos mais acalentados se realizariam. Mas Carlos não é nenhum Príncipe Encantado. Para sua tristeza, ele não usa um casaco preto de veludo de cauda longa e tampouco possui um chalé suíço com sacada. Para mostrar que Emma acredita não ser culpada por sua crescente insatisfação com Carlos, Flaubert emprega muitas comparações elegantes. Ele compara o que seria a resposta afetuosa e plena de Emma, caso Carlos fizesse o gesto correto, a uma fruta caindo da árvore quando sacudida. Certamente não é Emma que faz essa comparação; uma vez que ela chama atenção por ser bastante diferente dos milhares de clichês que Emma absorveu com a leitura de ficção romântica e sentimental. Mas não se pode ter certeza. Entretanto, a última frase do parágrafo, que trata da crescente indiferença de Emma por Carlos, claramente representa o ponto de vista avaliativo do narrador.

O segundo parágrafo contém dois métodos contrastantes de transcrição. As últimas duas frases, por exemplo, representam com bastante acuidade o que Emma está pensando; é concebível que ela possa usar exatamente as mesmas palavras: "Carlos nunca tivera curiosidade [...] enquanto residia em Ruão, de ir ao teatro ver os atores de Paris". Na primeira frase, contudo, a descrição, feita pelo narrador, da conversa de Carlos dificilmente poderia ser atribuída a Emma. Tanto a estrutura da frase quanto o conteúdo da comparação estão além de sua capacidade. Pois, a esta altura do romance, a rua simboliza, para Emma, não a grosseria da cidade, mas seu refinamento cultural. Mais tarde, ela chegará a se orgulhar de caminhar pelas ruas de Ruão nos braços de seu amante - somente no final do romance ela percebe que a cidade, assim como Carlos, não é mais uma solução para seus problemas. Estilisticamente, a comparação também aponta para a presença do narrador. Flaubert realiza a metáfora ao fazer as ideias de todos caminharem pela rua plana da conversa de Carlos. Os três substantivos, cuidadosamente localizados no final da frase, levam o pensamento à sua conclusão com uma cadência elegantemente entoada.

Frequentemente Flaubert não procura ocultar a personalidade do narrador na descrição da consciência de Emma: "Quanto à lembrança de Rodolfo, enterrara-a bem no fundo do coração; e lá estava, mais solene e imóvel que uma múmia real num subterrâneo. Mas uma exalação escapava desse grande amor embalsamado, atravessava tudo, perfumava de ternura a atmosfera de pureza em que ela pretendia viver." (p. 163). Esta pode ser uma paródia, mas é possível suspeitar que a passagem reflete o 
romantismo do narrador mais do que o sentimentalismo de Emma. Embora passagens como essa não apareçam em cada página de Madame Bovary, elas existem em número suficiente para fazer com que o romance seja narrado de forma menos objetiva do que Crime e castigo.

Se considerarmos Madame Bovary nosso teste de objetividade, podemos dizer que Crime e castigo é realmente objetivo. De fato, é difícil conceber um romance narrado de forma mais objetiva, dado o período em que foi escrito, visto que a maioria dos romances do século XIX apresenta, como parte de sua estrutura básica, um narrador significativamente personalizado, senão dramatizado. O que impressiona no narrador de Crime e castigo é que Dostoiévski o entrelaçou tão habilmente no texto, que ele, às vezes, é completamente negligenciado. Somente certa quantidade de exames críticos pode revelar que ele, de fato, carrega todas as funções tradicionais do narrador onisciente.

O narrador de Crime e castigo não apenas comenta a ação dos personagens, mas confere ao romance uma unidade de visão, frequentemente ausente em obras construídas com estilo mais conscientemente objetivo e impessoal. O simbolismo, o enredo e a caracterização não são os únicos elementos ficcionais que garantem essa unidade e a fazem pulsar com a vida. Talvez tão vital seja o tom da voz do romancista, a presença dramática, que E. M. Forster ${ }^{20}$ e Wolfgang Kayser ${ }^{21} \operatorname{argumentaram~ser~tão~}$ importante.

Estudiosos e críticos de Crime e castigo elogiaram-no repetidamente por sua notável unidade, que impressiona ainda mais quando comparada com outras grandes obras de Dostoiévski ${ }^{22}$. A maioria dos comentadores defende que essa unidade resulta da concentração quase exclusiva do autor no herói. Mochulsky, talvez o proponente mais articulado dessa posição, vê Raskólnikov como o centro dinâmico a partir do qual

\footnotetext{
${ }^{20}$ Aspects of the novel (Nova Iorque: Harcourt, 1927), p. 125-6. [Aspectos do romance. São Paulo: Globo, 2005].

${ }^{21}$ Entstehung und Krise des modernen Roman, $2^{\mathbf{o}}$ ed. (Stuttgart: J. B. Metzlersche Verlagsbuchhandlung, 1955), p. 34: "Ein für den Roman wesentliches Formprinzip... ist der Erzähler, vielleicht das wesentlichste." ["Um princípio formal essencial do romance... é o narrador, talvez o mais essencial"]. ${ }^{22}$ Cf. Joseph Warren Beach, The Twentieth Century Novel: Studies in Technique (Nova Iorque: Appleton, 1932), p. 157-161; G. I. Tchulkov, Kak rabotal Dostoiévski (M.: Sov. Pisatel, 1939), p. 141-2; Konstantin Mochulsky, Dostoevsky: His Life and Work, trad. Michael A. Minihan (Princeton: Princeton Univ. Press, 1967), p. 298-300; V. B. Chklovski, Za i protiv: Zametki o Dostoiévskom (M.: Sov. Pisatel, 1957), p. 1734; L. P. Grossman, "Dostoiévski - khudojnik". In: Tvortchcestvo F. M. Dostoiévskogo, ed. N. L. Stepanov (M.: AN SSSR, 1959), p. 392 [Dostoiévski Artista, trad. Boris Schnaiderman. Rio de Janeiro: Civilização Brasileira, 1967]; F. I. Evnin, "Roman 'Prestuplenie i nakazanie"” in: Tvortchcestvo F. M. Dostoiévskogo, p. 165-6; M. M. Bakhtin, p. 20-31; V. I. Etov, "Priemi psikhologuitcheskogo analiza v romane 'Prestuplenie i nakazanie"' Vestnik Moskovskogo universiteta, Seriia 10, Filologuiia, no 3 (1967), p. 3.
} 
todos os outros elementos do enredo, tema e caracterização, recebem suas definições ${ }^{23}$. Embora essa interpretação seja um tanto óbvia, ela permanece válida: Crime e castigo foi concebido como a história de um homem e um destino, e a opinião crítica aceitou essa visão.

Alguns estudiosos consideraram essa resposta muito simplista. L. P. Grossman, por exemplo, mostrou que, embora Crime e castigo nos deixe com a impressão de um todo admiravelmente unificado, ele é constituído por um amálgama de materiais heterogêneos. Aspectos de esboço psicológico, de mistério do assassinato e de romance gótico são livremente combinados com confissões, passagens bíblicas, cartas e debates filosóficos. Como Dostoiévski pôde - ele se pergunta - de maneira tão fácil e bem sucedida combinar elementos dos mais discrepantes e aparentemente incompatíveis tanto da narrativa ficcional quanto não-ficcional? A resposta - ele afirma - deve ser encontrada no enredo, e não na caracterização. Dostoiévski cria unidade artística ao submeter os materiais heterogêneos de sua estória ao dinamismo de seu enredo. Desse modo, é capaz de construir um romance de grande importância metafísica em torno das impressionantes intrigas do roman feuilleton. Para Grossman, a velocidade estonteante dos acontecimentos não permite ao leitor focar os tijolos individuais da estrutura. É quase como se o enredo fosse um cadinho no qual os elementos se fundem, perdendo sua forma e função originais ${ }^{24}$. De fato, qualquer um que tenha sido apanhado pelo enredo de Crime e castigo pode facilmente apreciar a hipótese original de Grossman. Embora seja difícil de demonstrar, trata-se de um complemento interessante e necessário à interpretação, talvez um tanto unilateral, de Mochulsky.

A abordagem mais ousada a Crime e castigo é a de Bakhtin, que vê sua unidade não nas formas tradicionais de enredo e caracterização, mas em seu ponto de vista polifônico. Conforme esbocei anteriormente, Bakhtin defende que, em todos os romances de Dostoiévski depois de Memórias do subsolo, cada personagem representa uma visão do mundo igualmente válida, que de modo algum é subordinada àquela do narrador ou autor. A unidade de Crime e castigo é, portanto, uma unidade paradoxal de diversidade e mesmo de discórdia, é a unidade de uma dialética sem fim de visões de

\footnotetext{
${ }^{23}$ Mochulsky, p. 298.

${ }^{24}$ L. P. Grossman, Poétika Dostoiévskogo (M.: Gos. akad. khud. nauk, 1925), p. 74-80; e "Dostoiévski khudojnik", p. 371-85.
} 
mundo, cada qual tateando em direção de sua própria compreensão da realidade. É, assim, uma unidade dinâmica, pois que é processo, não ideia ${ }^{25}$.

Os críticos de Bakhtin, entretanto, defendem, de modo convincente, que as vozes dos romances de Dostoiévski não possuem de forma alguma a mesma validade e independência $^{26}$. Simbolismo, enredo e caracterização em Crime e castigo, assim como na maioria de seus romances, estão todos subordinados a um quadro de referência superior cuidadosamente trabalhado. Não obstante, as teorias de Bakhtin ao menos nos obrigam a lidar com o papel do narrador como elemento unificador do romance. Pois nem a teoria de Grossman sobre o enredo, nem a de Mochulsky sobre a personagem explicam completamente a unidade do romance - especialmente à luz do epílogo.

Em contraste direto com a tese de Bakhtin, o objeto desse estudo é demonstrar em que medida os pontos de vista dos personagens de Crime e castigo estão subordinados ao ponto de vista elevado do narrador. A estrutura avaliativa subjacente de Crime e castigo deve, certamente, ser encontrada no simbolismo e em outros procedimentos de caracterização e enredo que podem ser atribuídos ao autor implícito. Mas Dostoiévski, vez por outra, faz uso do narrador pessoalizado para transmitir essas normas para o leitor. Justamente por não recuar aos fatos anteriores, ele pode servir como uma espécie de inteligência central que subordina todos os pontos de vista ao seu. Por fim, é a esse ponto de vista elevado e pessoalizado que Crime e castigo deve sua admirável unidade.

Essa unidade é altamente intensificada pela habilidade do narrador de usar o epílogo, não só como meio de tornar explícito o que estava implícito no romance, como de sintetizar o material heterogêneo da história. Pois é somente no epílogo que o passado, o presente e o futuro aparecem como um padrão cuidadosamente arranjado por um ponto de vista elevado. O epílogo conclui o jogo moral do narrador; é o momento da revelação de toda a amplitude de seu conhecimento. E isso inclui o conhecimento de tudo o que se passou e do que virá.

O ponto de vista elevado de Crime e castigo compreende não somente um sistema de valores pelo qual os personagens são julgados, mas a visão de mundo que subjaz esse mesmo sistema. Pois, ainda que sejam relatados de modo objetivo, os acontecimentos de Crime e castigo não se passam somente no mundo objetivo. Nas

\footnotetext{
${ }^{25}$ Bakhin, p. 20-1.

${ }^{26}$ Cf. A. V. Lunatchárski, “O mnogogolosnosti Dostoiévskogo” In: F. M. Dostoiévski v russkoi kritike: Sborknik statei, Ed. A. A. Belkin (M.: GIXL, 1956).
} 
últimas frases da passagem final do romance, o narrador fala do encontro de Raskólnikov com uma forma de ser desconhecida para a dialética do intelecto racional fechado em si mesmo: "Mas aqui já começa outra história, a história de renovação gradual de um homem, a história do seu paulatino renascimento, da passagem progressiva de um mundo a outro, do conhecimento de uma realidade nova, até então totalmente desconhecida. Isto poderia ser o tema de um novo relato - mas este está concluído" (p. 561).

O novo mundo e a realidade não sonhada não existem somente no futuro de Raskólnikov, eles estão na fundação de todos os acontecimentos do romance. Trata-se de uma realidade superior que é a um tempo transcendente e imanente, e que se revela com toda força no epílogo. Não constitui, todavia, um plano de existência encontrado com frequência no romance oitocentista, e isso talvez explique porque tantos críticos consideraram imperfeita a caracterização de Sônia, rejeitaram o epílogo como artisticamente injustificado e ignoraram a importância da realidade metafísica na obra. Para eles, Crime e castigo, como qualquer romance do século XIX, tem seu fundamento no mundo dos fenômenos.

Para maioria da crítica dos gêneros narrativos, o romance é definido não somente em termos formais de caracterização, enredo, simbolismo e afins, mas pela natureza de seu universo ficcional. É considerado, em geral, uma narrativa em prosa que apresenta seus personagens em papéis sociais - como diz Fielding, trata-se de um épico cômico em prosa. E, como tal, é frequentemente visto, diferentemente da estória romanesca, como tendo um forte fundamento na realidade material objetiva. Nesse sentido, a estória romanesca tem uma latitude muito maior do que o romance. Assim, Northrop Frye, em sua Anatomia da crítica, eloquentemente expressou a diferente abordagem da caracterização entre os gêneros:

O autor romanesco não tenta criar "gente real", tanto quanto figuras estilizadas que se ampliam em arquétipos psicológicos. [...] É por isso que a estória romanesca irradia tão frequentemente um brilho de intensidade subjetiva que o romance não tem, e é por isso que uma sugestão de alegoria está constantemente insinuando-se por volta de suas orlas. Certos elementos da personalidade são libertados na estória 
romanesca, os quais naturalmente a tornam um tipo mais revolucionário do que o romance. ${ }^{27}$

Seria certamente um exagero, senão incorreção, classificar Crime e castigo como estória romanesca e não romance; ainda assim seu universo tem muitas afinidades com a primeira, na qual as leis da realidade objetiva são suplantadas. Embora o mundo social contemporâneo desempenhe um papel importante em Crime e castigo, ele é, ao fim e ao cabo, menos crucial para o romance do que a ordem metafísica que o sustenta ${ }^{28}$. Esse certamente não é o caso da maioria dos romances oitocentistas, nos quais as vidas dos personagens estão totalmente encerradas na realidade material objetiva. Jane Austen e Emile Zola, guardadas as devidas proporções, compartilham pressuposições filosóficas sobre o mundo que os separam de escritores idealistas como Hoffmann, Gógol e Dostoiévski.

É função do narrador pessoalizado persuadir o leitor a aceitar, pelo menos artisticamente, a validade do universo ficcional de Crime e castigo. Se o romance se mantém como um todo orgânico, o leitor deve estar convencido de que a realidade religiosa, que se manifesta tão vigorosamente no epílogo, não é uma superposição gratuita, mas uma força objetivamente existente que, não somente influencia os personagens, mas oferece-lhes escolhas concretas e significativas. O narrador garante que isso seja assim. Um narrador totalmente objetivo, por outro lado, teria certamente nos deixado com a forte possibilidade que o Deus de Sônia fosse, como Raskólnikov sugere, simplesmente um sintoma de sua mania religiosa.

A subestrutura religiosa do romance não é meramente sugerida, mas se sustenta por inúmeros detalhes ao longo do romance. Mesmo críticos ocidentais tenderam a ignorar as evidências. Pouca atenção foi dedicada, por exemplo, às causas latentes da regeneração de Raskólnikov; ainda assim, talvez seja um tanto injustificado da nossa parte admitir que Dostoiévski tenha simplesmente deixado de ancorar a ressurreição na personalidade de Raskólnikov; que ele tenha colocado todo o fardo da prova na natureza inescrutável do milagre religioso - o que certamente seria uma saída filosoficamente

\footnotetext{
${ }^{27}$ Anatomia da crítica. Trad. Péricles Eugênio da Silva Ramos. São Paulo: Cultrix, 1973, p. 299.

${ }^{28}$ Dostoiévski sempre foi profundamente consciente de que, no fundo, seu realismo estava mais próximo do idealismo do que do realismo de seus contemporâneos. Como todos os idealistas, ele defende que seu idealismo é mais real do que o realismo dos chamados realistas. Para suas inúmeras afirmações sobre o realismo em sua própria obra e nas obras de outros, cf. Sven Linnér, Dostoevskij on Realism (Estocolmo: Almquist and Wiksell, 1967).
} 
plausível, mas dificilmente crível e satisfatória esteticamente ${ }^{29}$. Sabemos, por exemplo, a partir da carta de sua mãe, que Raskólnikov teve uma criação religiosa rígida, que ele balbuciava suas orações no colo da mãe, e que acreditava na misericórdia de "nosso Criador e Salvador". Naquele tempo ele era inquestionavelmente feliz. No primeiro sonho, lembra-se que, quando criança, sempre que visitava o túmulo de seu irmão menor, costumava benzer-se de forma religiosa e respeitosa, fazer-lhe reverência e beijá-lo. Ele se lembra de como amava a igreja para a qual era levado duas ou três vezes por ano para assistir a uma missa em memória de sua avó.

Também não é estranho que ele parasse no meio do caminho para a universidade precisamente no local onde a cúpula da Catedral de São Isaac brilhasse com o mais deslumbrante esplendor. Paralisado, ele olha admirado esse "panorama realmente magnífico e sempre chegando quase a surpreender-se com uma impressão vaga e sem solução" (p. 128). Embora esse espetáculo lhe causasse frio depois do assassinato, estamos conscientes de que Raskólnikov carrega dentro de si as sementes de uma nova realidade, as quais, no passado, foram lançadas por esta bela visão, e que irão florescer quando ele tiver expiado sua transgressão ${ }^{30}$.

Especialmente significativa, em relação às crenças de Raskólnikov, é a cena em que ele explica seu artigo sobre o crime à Porfíri. Ele menciona a Nova Jerusalém e pergunta se Raskólnikov acredita nela. Porfíri pressiona:

- E... e... e... em Deus, acredita? Desculpe tanta curiosidade.

- Acredito - repetiu Raskólnikov, levantando a vista para Porfíri.

- E... e na ressurreição de Lázaro, acredita?

- Ac-acredito. Por que lhe interessa tudo isso?

- Acredita literalmente?

- Literalmente.

- Então é assim... eu estava curioso. Desculpe. (p. 270)

\footnotetext{
${ }^{29}$ Para uma discussão da representação artística do milagre em Dostoiévski ver L. A. Zander, Dostoevsky, trad. Natalie Duddington, (Londres, SCM Press, 1948), p. 15-25.

${ }^{30}$ Há outros fatos importantes que apontam para o lado religioso latente de Raskólnikov. Depois do sonho com o espancamento da égua, Raskólnikov reza a Deus para mostrar-lhe o caminho pelo qual ele pudesse renegar esse "maldito... sonho meu" (p. 75). Ele pede a Poliétchka (p. 200) para rezar por ele quando ela o convida para as exéquias de seu padrasto (Marmieládov). No fim do romance, com profunda seriedade, ele pede à mãe que reze por ele (p. 522).
} 
Críticos soviéticos interpretaram a Nova Jerusalém dessa passagem como uma alusão à utopia socialista de Saint-Simon ${ }^{31}$. Mas essa interpretação não explica satisfatoriamente as outras respostas de Raskólnikov para as questões que lhe são colocadas; pois ele diz a Porfíri que não apenas acredita em Deus, mas também na ressurreição de Lázaro dos mortos. Porfíri obviamente compartilha as mesmas dúvidas do leitor, por isso, Dostoiévski o faz perguntar a Raskólnikov se ele acredita na ressurreição de Lázaro literalmente. Raskólnikov responde afirmativamente. Além disso, a cena em que Sônia lê essa passagem mostra que. pelo menos alguma parte dele, está falando a verdade quando ele diz acreditar literalmente. O pedido de Raskólnikov para que Sônia leia o excerto constitui uma evidência psicológica de seu anseio, ainda que reprimido, por acreditar na possibilidade de salvação.

Mas a cena de Lázaro faz mais do que simplesmente oferecer uma prova da religiosidade latente de Raskólnikov; ela revela a visão religiosa subjacente ao romance por meio do narrador:

\begin{abstract}
- Eis tudo sobre a ressurreição de Lázaro - sussurrou ela com voz entrecortada e severa, e ficou imóvel, virada para um lado, sem se atrever e como se sentisse vergonha de levantar os olhos para ele. Seu tremor febril ainda continuava. O toco de vela há muito se extinguia no castiçal torto, iluminando frouxamente naquele quarto miserável um assassino e uma devassa, que se haviam unido estranhamente durante a leitura do livro eterno. Transcorreram uns cinco minutos ou mais. (p. 338-9)
\end{abstract}

Conforme foi mostrado no Capítulo 6, essa passagem claramente indica que o narrador acredita na validade da Bíblia e, consequentemente, nas implicações que ela tem tanto para o herói quanto para a heroína. A linguagem é solene, não há ironia. Uma vez que ele provou ser absolutamente confiável anteriormente, o leitor é compelido a aceitar as verdades bíblicas como válidas, não somente para a cena de Lázaro, mas para todo o romance. Suspendemos nossa descrença, pois o ponto de vista do narrador não é, como defende Bakhtin, apenas mais uma opinião, mais um ponto de vista elevado, que o leitor passa a aceitar e confiar.

\footnotetext{
${ }^{31}$ Cf., por exemplo, V. Ia. Kirpotin, Razotcharovanie i kruchenie Rodiona Raskolnikova (M.: Sov. Pisatel, 1972) p. 111; G. F. Kogan, CP, p. 756.
} 
As frases do narrador no epílogo com relação à experiência de Raskólnikov de uma realidade até então desconhecida constituem a visão de mundo metafísica do romance. Seu relato exultante da transformação de Raskólnikov e a visão menos crítica das crenças de Sônia garantem ao leitor que a realidade religiosa, ainda que sutilmente representada no romance, é, não obstante, vigorosa; eles asseguram que esta é a realidade fundamental. $\mathrm{O}$ narrador onisciente pessoalmente atesta a autenticidade dos eventos. Portanto, ele não apenas unifica Crime e castigo ao subordinar todos os pontos de vista ao seu, com também valida o universo ficcional do qual a máxima relevância desses pontos de vistaé derivada.

Tradução: Priscila Nascimento Marques ${ }^{32}$

${ }^{32}$ Mestre e doutora em Literatura e Cultura Russa pela Faculdade de Filosofia, Letras e Ciências Humanas da Universidade de São Paulo (FFLCH-USP). A presente tradução é parte dos resultados da pesquisa de mestrado Polifonia e emoções: um estudo sobre a construção da subjetividade em Crime e castigo de Dostoiévski (2010), realizada com apoio da Fapesp. Contato: pri_nmarques@yahoo.com.br 